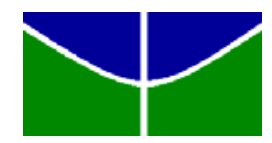

Universidade de Brasília

Faculdade de Economia, Administração, Contabilidade e Ciência da Informação e Documentação Departamento de Ciência da Informação e Documentação

Graduação em Biblioteconomia

\title{
Organização e preservação de livros raros na Biblioteca Nacional do Rio de Janeiro
}

\author{
Suelen Garcia Soares
}


Suelen Garcia Soares

\section{Organização e preservação de livros raros na Biblioteca Nacional do Rio de Janeiro}

Monografia apresentada ao Departamento de Ciência da Informação e Documentação da Universidade de Brasília, como requisito parcial para obtenção de título de Bacharel em Biblioteconomia.

Orientadora: Profa. Dra. Miriam Paula Manini 
S676o Soares, Suelen Garcia.

Organização e preservação de livros raros da Biblioteca Nacional do Rio de Janeiro / Suelen Garcia Soares. - Brasília, 2009

92 p. : il.

Orientação: Profa. Dra. Miriam Paula Manini

Monografia (graduação) - Universidade de Brasília, Departamento de Ciência da Informação e Documentação, 2009.

1. Livro raro. 2. Biblioteca Nacional. 3. Biblioteconomia de livros raros. 4. Preservação 3. Conservação 4. Restauração I. Soares, Suelen Garcia. II. Manini, Miriam Paula (orient.) III. Título. 


\section{Agradecimentos}

Agradeço a Deus, pela onipresença nos momentos e decisões de minha vida.

Agradeço a Maria Santíssima pelo consolo diário nas tribulações da vida.

Agradeço ao meu pai, Torquato Soares, pelo o amor, por ser exemplo de pai, pela educação e formação do meu caráter.

À minha mãe, Maria das Graças, pelo amor, dedicação e confiança. Ela que acreditou no meu sonho de estudar na Universidade de Brasília e não mediu esforços para me ajudar alcançar esse sonho. Ela que não me criticou pela decisão de mudança de opção de curso. Ela que é meu exemplo de amor ao próximo.

Às minhas irmãs, Graciely e Gabrielle, que me ajudaram a entender que família é o mais importante na vida.

À Tia Anita pela recepção em sua casa. Ela que não mediu esforços para que tudo desse certo durante a minha estadia na cidade do Rio de Janeiro.

A todos meus amigos e amigas pelas orações e compreensão nos momentos que abdiquei buscando a realização de sonhos.

De modo especial agradeço a minha amiga Welma, com a qual construí uma amizade sincera e verdadeira.

À professora Miriam Manini pela confiança na minha capacidade de desenvolver uma pesquisa desse tipo. Pela orientação, leitura e sugestões no meu texto.

Agradeço pelo carinho e atenção de todos da Coordenadoria de Preservação e à Divisão de Obras Raras da Biblioteca Nacional. Em especial a Ana Virginia, Luís Antonio, Cristina, Ana Paula, André, Jayme Spinelli, Silvana Bojanoski, Tatiana Ribeiro e Silvio, todos vocês contribuíram e são de alguma maneira co-autores do trabalho que escrevi.

E por fim agradeço a todos aqueles que de alguma maneira contribuíram para a minha formação acadêmica. 
Todo bibliotecário é, até certo ponto, um arquiteto. Ele constrói a coleção como um conjunto em que o leitor tem que encontrar o caminho, descobrir a si mesmo e viver. 


\section{Resumo}

A pesquisa tem um caráter descritivo, consiste em um estudo de caso da Biblioteca Nacional do Rio de Janeiro, uma das instituições brasileiras com mais experiência em organização e preservação de livros raros. Objetivo central é identificar e descrever as práticas adotadas por essa instituição em relação ao Programa de formação e desenvolvimento de acervo de livros raros e ao Programa de preservação dessas obras. A Biblioteca Nacional possui um acervo de aproximadamente nove milhões de volumes. É considerada pela UNESCO a primeira biblioteca da América Latina e a oitava do mundo em termos de qualidade de seu acervo. Desde a década de quarenta estudiosos consideravam seu acervo como um dos mais valiosos do mundo. A pesquisa buscou esclarecer certos mitos a respeito do livro raro, como esclarecer de onde veio a idéia de que todo livro raro é um livro antigo. Buscou-se conhecer o que a Biblioteconomia de livros raros revela a respeito de organização desse tipo de coleção. Destacou a importância de uma elaboração de política de preservação para uma coleção de livros raros e como o bibliotecário de livros raros deve participar desse processo. Fez-se um breve histórico da Biblioteca Nacional. A análise dos dados revela práticas exercidas quanto à organização e preservação de livros raros pela a Divisão de Obras Raras e a Coordenadoria de Preservação da Biblioteca Nacional.

Palavras chaves:

Livro raro; Biblioteca Nacional; Biblioteconomia de livros raros; Preservação. 


\begin{abstract}
The present paper consists on a study case over the National Library of Rio de Janeiro, one of most experienced institutions in Brazil in organization and keeping of rare books. The main goal is to identify and describe the policies adopted by that institution related to the Rare books Formation and Development of Collection Program and its preserving program as well. The National Library has a collection of approximately nine million volumes, considered by UNESCO (United Nations Education Science and Culture Organization) the first library in South American and the eighth in the world the collection quality criteria. Since the 1940, researchers consider its collection one of the most valuables of world. This paper intended to enlighten certain myths about rare books as well as the idea all rare book are old books. Aimed to know what rare books librarianship reveals regarding the organization of this kind of collection. Highlighted the relevance of elaborating a preservation policy for rare book collections and how the librarian should participate on this process or action. A brief historic is also brought in this work . The data analysis shows all policies performed that are related to the rare book organization and preservation by the Rare Book Collection Division and by the National Library Coordination of Preservation.
\end{abstract}

Keywords: Rare book; National Library of Rio de Janeiro; Rare Book Librianship; Preservation policy 


\section{Lista de figuras}

Figura 1: Exemplo de iluminura.........................................................................

Figura 2: Volume da Bíblia de Mogúncia da Biblioteca Nacional do Rio de Janeiro. 20

Figura 3: Novo tipo de acondicionamento - vista lateral e vista superior. 73

Figura 4: Demonstração de douração com componedor manual e atual máquina de douração. 74

Figura 5: Modelos de Encadernação Flexível de pergaminho. 78 


\section{Sumário}

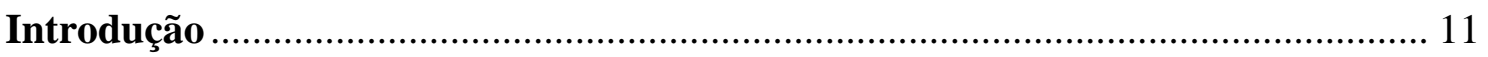

\section{Capítulo I}

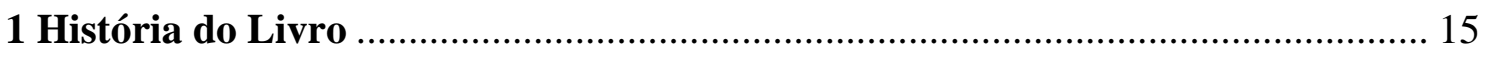

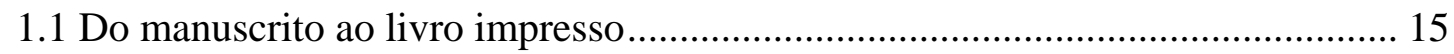

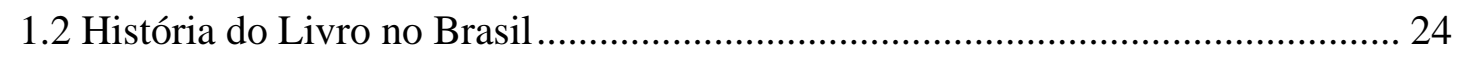

\section{Capítulo II}

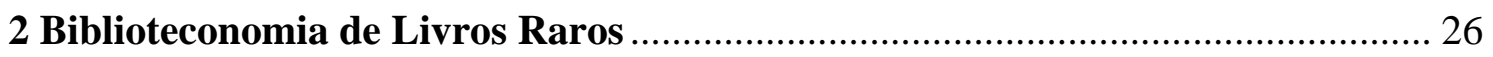

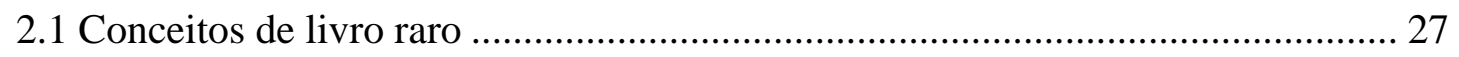

2.2 Desenvolvimento e formação de acervos de livros raros ..................................... 30

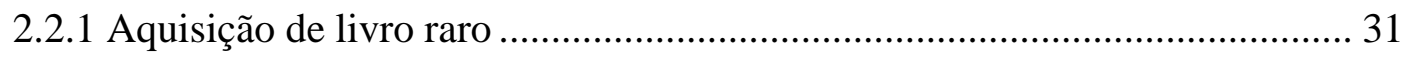

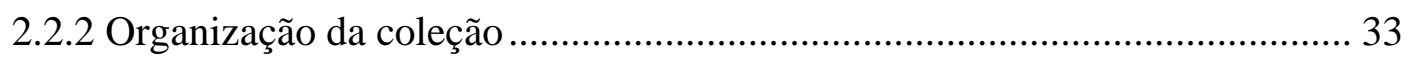

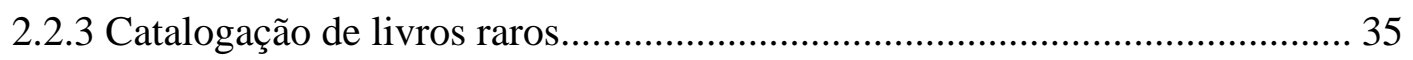

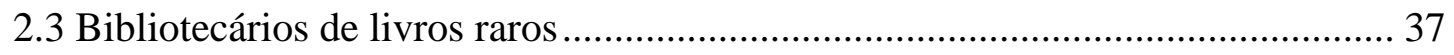

\section{Capítulo III}

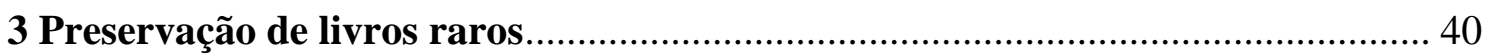

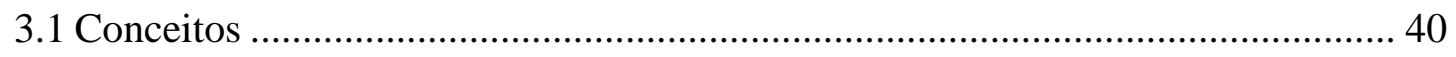

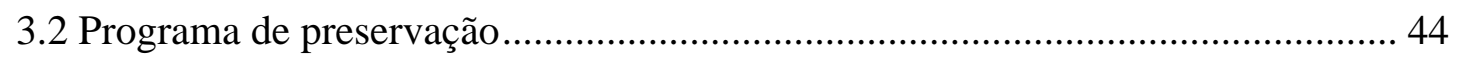

3.3 Programa de prevenção de emergências............................................................... 47

3.4 Segurança contra roubos em acervos raros..................................................... 49

\section{Capítulo IV}

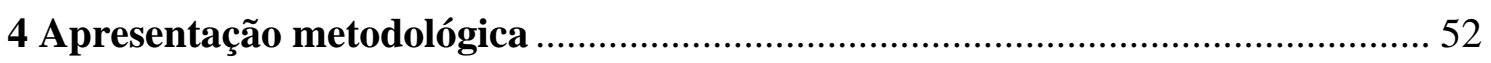

\section{Capítulo V}

5 Breve Histórico da Biblioteca Nacional. 54 


\section{Capítulo VI}

6 Estudo de Caso. 57

6.1 Organização de livros raros na Biblioteca Nacional .......................................... 57

6.2 Preservação de Livros Raros na Biblioteca Nacional.......................................... 68

6.2.1 Centro de Conservação e Encadernação - CCE ........................................... 70

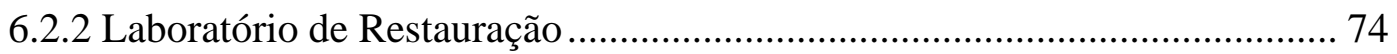

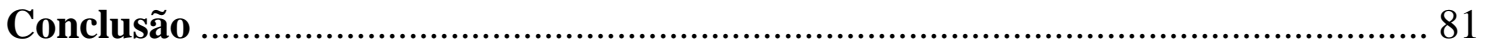

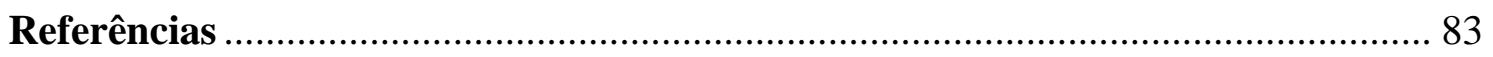

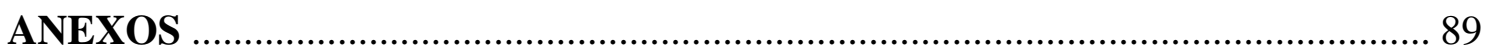

Anexo A - Exemplo de ficha catalográfica com notas atualizadas e com acesso ao

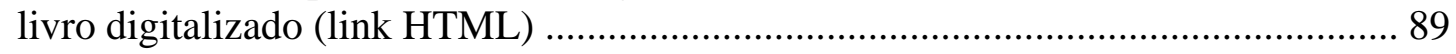

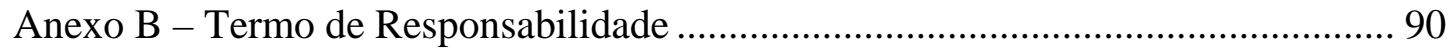

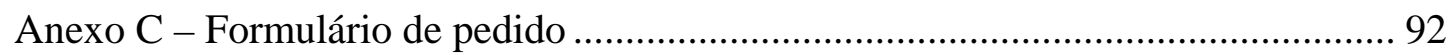




\section{Introdução}

A Biblioteca Nacional de um país é uma instituição que visa à preservação do patrimônio intelectual da nação. De acordo com Campelo (2006) é um órgão mantido pelo poder público e subordinado a uma das instâncias administrativas de mais alta hierarquia do governo central ou federal. O nascimento da idéia de biblioteca nacional surgiu com advento dos Estados nacionais modernos e com os esforços feitos para consolidação da ciência e da cultura nacional.

Em 1977, a UNESCO (Organização das Nações Unidas para a Educação, a Ciência e a Cultura) e a IFLA (International Federation of Library Associations and Institutions) promoveram o Congresso Internacional sobre Bibliografias Nacionais. Nesse evento as duas instituições propuseram as diretrizes para o programa de Controle Bibliográfico Universal. Antes dessa data já era conhecido entre bibliotecários o conceito de controle bibliográfico, que consiste em um arranjo de técnicas e procedimentos cujo objetivo é organizar determinado conjunto de suportes de informação para torná-los acessíveis, da forma mais eficiente possível, a qualquer indivíduo que dele necessite (CAMPELO, 2006).

A partir dessas diretrizes, as bibliotecas nacionais ampliaram suas funções. Além de preservar o patrimônio cultural nacional, desempenham o papel de agência bibliográfica nacional. Essa é responsável pela coordenação dos mecanismos de depósito legal e o cumprimento dele; elaboração da bibliografia nacional; padrões para uniformização e geração dos registros ISBD (International Standard Bibliographic Description); e atuação como agência central de catalogação.

Atualmente, conforme Campelo (2006, p. 27) uma biblioteca nacional pode seguir três orientações diferentes:

1. Função depositária: ênfase na preservação da herança cultural do país, representada por extensa coleção de materiais. As que seguem essa orientação são, geralmente, as mais antigas e suas atividades voltam-se predominantemente para a conservação do acervo.

2. Função de infra-estrutura: ênfase na coordenação, liderança e serviço às bibliotecas do país. As que seguem essa orientação são, em geral, mais novas.

3. Função de serviço nacional abrangente: nesse caso, estão as bibliotecas nacionais que direcionam seus serviços para o usuário final, atendendo a 
pessoas do país inteiro, mediante o sistema de bibliotecas públicas. Esse tipo de orientação é encontrado em bibliotecas nacionais de países em desenvolvimento.

No caso da Biblioteca Nacional do Brasil, ela realiza as três funções. Segundo o Estatuto da Fundação Biblioteca Nacional, regulamentado pelo decreto n. 5038 de 2004, a Biblioteca Nacional é o órgão responsável pela execução da política governamental de recolhimento, guarda e preservação da produção intelectual do País e tem por finalidade:

I - adquirir, preservar e difundir os registros da memória bibliográfica e documental nacional;

II - promover a difusão do livro, incentivando a criação literária nacional, no País e no exterior, em colaboração com as instituições que a isto se dediquem;

III - atuar como centro referencial de informações bibliográficas;

IV - registrar obras intelectuais e averbar a cessão dos direitos patrimoniais do autor;

V - assegurar o cumprimento da legislação relativa ao Depósito Legal;

VI - coordenar, orientar e apoiar o Programa Nacional de Incentivo à Leitura;

VII - coordenar o Sistema Nacional de Bibliotecas Públicas;

VIII - elaborar e divulgar a bibliografia nacional; e

IX - subsidiar a formulação de políticas e diretrizes voltadas para a produção e amplo aceso ao livro.

Em seus quase 200 anos de história, a Biblioteca Nacional é considerada pela UNESCO a maior Biblioteca Nacional da América Latina e a oitava no mundo. Possui aproximadamente nove milhões de documentos em diversos suportes, adquiridos através de permuta, doações, compra e, principalmente, por meio da Lei do Depósito Legal. No acervo existem preciosidades como a Bíblia de Mogúncia (1462), manuscritos e desenhos originais de expedições científicas realizadas no Brasil (séculos XVI a XIX); desenhos brasileiros, que refletem momentos importantes da história da arte no país.

Segundo o Relatório de gestão de 2004 da Fundação Biblioteca Nacional, a Biblioteca desempenha papel estratégico no estabelecimento de uma política nacional do livro e da leitura. Coordena, em âmbito nacional, o Sistema Nacional de Bibliotecas Públicas, o Programa Nacional de Incentivo à Leitura (PROLER), o Plano Nacional de 
Obras Raras (PLANOR) e o Plano Nacional de Microfilmagem de Periódicos Brasileiros (PLANO).

A Biblioteca Nacional tem como um dos seus principais objetivos promover a divulgação e a difusão do seu acervo e serviços, com a finalidade de alcançar a todos os brasileiros e implantar o sentimento de importância do patrimônio cultural do Brasil. Para alcançar esse objetivo, criou a Biblioteca Digital do Brasil, que permite o acesso remoto a resultados de diversos projetos promovidos com intenção de preservação e divulgação do acervo da Biblioteca.

A visita do bibliográfo William Vernon Jackson, um dos maiores brasilianistas do mundo, em 1945, à Biblioteca Nacional do Rio de Janeiro, com o objetivo de examinar o estado dos livros raros e de propor soluções para sua conservação, contribuiu para a reorganização e a valorização da coleção de obras raras. Em relatório, Jackson declarou que se tratava de uma das maiores e melhores coleções de livros raros não encontrados em qualquer outro país da América Latina e, quiçá, do mundo. (BANDEIRA, 2007).

Justifica-se, desta forma, a importância desta pesquisa, que tem como objetivo central descrever as práticas de organização e preservação da coleção de livros raros da Biblioteca Nacional.

No Capítulo 1, dedicado à história do livro, procura-se entender por que o conceito de livro raro está tão ligado à Antiguidade. A intenção não é relatar a origem do livro, tampouco o uso dos primeiros suportes da escrita, mas demonstrar quão importante foi a criação do livro impresso para a divulgação e disseminação de novos conhecimentos. Relata-se, de maneira breve, a história do livro no Brasil, com a intenção de registrar a importância como raridade, de um primeiro impresso em um país.

O Capítulo 2 é, dedicado à Biblioteconomia de livros raros; nele é feita a distinção entre o conceito de livro raro e o de obras raras. Optou-se pelo conceito livro raro, pois a literatura, mesmo quando usa obras raras, refere-se a livro raro.

A intenção no Capítulo 3 é frisar a importância do conhecimento em preservação por bibliotecários, que são os verdadeiros guardiões de coleções especiais. A literatura faz diferenciação dos métodos de Conservação e de Restauração de acervos gerais e coleções especiais. Procura-se destacar que também faz parte do universo da Preservação a segurança do acervo e o controle contra sinistros e incêndios. 
$\mathrm{Na}$ análise dos dados, ficou claro que a cada ano que passa, a Biblioteca Nacional vem construindo um papel de referência nacional de preocupação com a preservação e acesso a seu acervo. Por ser uma Biblioteca de Memória, todas as atividades por ela exercidas, da limpeza dos banheiros à limpeza dos armazéns, da preocupação com a segurança do acervo à consciência de todos os funcionários, tudo gira em torno da Preservação da Memória Intelectual e Cultural do Brasil. 


\section{Capítulo I}

\section{História do Livro}

\subsection{Do manuscrito ao livro impresso}

Quando se pensa em obra rara, tem-se a idéia de livro antigo e velho. É interessante notar o que estudiosos do assunto comentam sobre esse fato:

Os bibliotecários pensam não ter quaisquer dúvidas por que se baseiam, comumente, no consenso generalizado: "VELHO-ANTIGO-RARO". Obviamente, apenas a antiguidade de uma obra não caracteriza a sua raridade. Rara pode ser mesmo uma publicação da década de oitenta (PINHEIRO, 1989, p. 20).

O fato de o livro ser antigo certamente me atraiu quando comprei o primeiro, aos treze anos. [...]. Depois aprendi que a idade do livro em si não tem tanta importância. O que importa é o conteúdo da obra, o valor histórico ou gráfico da edição. E muitos outros fatores (MINDLIN, 1997, p. 50).

Costumamos, geralmente, associar a obra rara ao "livro velho". Mas na verdade, para ser raro um livro não precisa necessariamente ser antigo, embora o critério de antiguidade seja o primeiro a ser considerado na identificação da obra rara (NARDINO; CAREGNATO, 2005, p. 383).

Um livro não é valioso porque é antigo e, provavelmente, raro. Existem milhões de livros antigos que nada valem porque não interessam a ninguém. Toda biblioteca pública está cheia de livros antigos, que, se fossem postos à venda, não valeriam mais que o seu peso como papel velho. $\mathrm{O}$ valor de um livro nada tem a ver com a sua idade. A procura é que torna um livro valioso (MORAES, 2005, p. 67).

Essa associação da idade do livro com raridade bibliográfica está diretamente relacionada com a história do livro e da bibliofilia. Sabe-se que, desde o início das 
civilizações, o homem fez uso de diversos suportes para o registro de informações de caráter intelectual, comercial e de acontecimentos do cotidiano.

De acordo com a história do livro, houve uma evolução de um suporte para outro: da argila para o papiro, do papiro para o pergaminho e do pergaminho para o papel. Essa escala de substituição é diferente de uma civilização para outra. No que diz respeito à civilização ocidental, começou-se a pensar em livro como objeto na Roma Antiga.

\begin{abstract}
Um livro romano compunha-se de folhas de papiro ou pergaminho unidas numa tira contínua, repartida em quadros margeados, e enrolada em torno de um cilindro. Capeava o volume uma folha mais encorpada, na qual em letras graúdas ia o título. Empregava-se no texto uma tinta feita de goma e pós de sapatos. O gosto e o fausto dos bibliófilos, transferidos depois às encadernações, pompeavam na decoração a ouro e púrpura da capa e nos lavores das córnuas, às vezes talhados em ébano ou marfim, embutidos de prata e ouro e até cravejados de pedras preciosas. Para perfumar e preservar o volume, embebia-se o rolo em óleo de cedro. (RIZZINI, 1946, p. 16).
\end{abstract}

Segundo Frieiro, intelectual mineiro, fundador e primeiro diretor da Biblioteca Pública de Minas Gerais, em seu livro Os livros nossos amigos, um ensaio sobre sua paixão por livros, a bibliofilia é tão “velha como o livro” e data desde a Antiguidade. De acordo com o autor:

No tempo de Sêneca, que via na moda do livro pelo livro um sintoma de corrupção social, as bibliotecas particulares se multiplicavam, instaladas em salas de estilo asiático, com as estantes incrustadas de marfim e metais preciosos. Milhares de copistas - os "impressores" da época - tornavam os manuscritos acessíveis até as classes menos favorecidas. O bibliômano do tempo dos Césares costumava dissipar sua riqueza em livros. (FRIEIRO, 1941, p. 80).

Segundo Febvre e Martin (2000, p. 12), costuma-se dividir em dois grandes períodos a evolução do livro manuscrito na Europa ocidental: Período Monástico e Período Laico. O Período Monástico tem a duração de sete séculos e vai desde a queda do Império Romano até o século XII, quando, de fato, nos mosteiros e em outros estabelecimentos eclesiásticos conservou-se o monopólio quase integral da cultura livresca e da produção do livro. 
Para Frieiro (1941, p. 81), neste período “a bibliofilia desapareceu por espaço de vários séculos, só reaparecendo, na Renascença, com a difusão do papel e a quase extinção dos livros em pergaminho”.

Os livros manuscritos eram ornamentados; muitas vezes tinham ilustrações, podendo ser iluminuras ou miniaturas. Miniaturas, segundo Mello (1972, p. 123), vêm da aplicação do minium (sulfato de mercúrio ou cinábrio, usado na preparação da tinta vermelha); foi utilizado pelos copistas para ornamentar as letras e as figuras. Já a iluminura referia-se, sobretudo, ao uso de douração e, portanto, um manuscrito iluminado seria, no sentido estrito, aquele decorado com ouro e prata. Para McMurtrie (1965, p. 81), “a iluminura contribuiu muito para a beleza dos livros manuscritos”. Com o aumento da procura pelos livros, “o impulso foi tornar maiores as letras iniciais de novas frases e colori-las algumas vezes. Florearam-se então as extremidades destas letras e depressa estes enfeites se complicaram estendendo-se pelas margens da página”. As principais cores empregadas eram o vermelho, o azul e o dourado, com menos uso a púrpura, o amarelo, o verde, o negro retinto e o branco.

Figura 1: Iluminura ${ }^{1}$

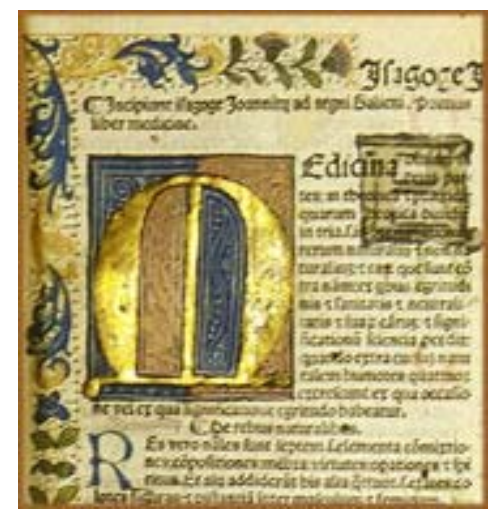

No final do século XII e início do XIII, o aparecimento e o desenvolvimento das universidades deram origem a um novo público leitor e passou a haver a necessidade de possuir manuscritos para os estudos acadêmicos. As universidades começaram a organizar bibliotecas para disponibilizar as obras que auxiliariam os estudos dos eruditos. É interessante notar que, nessa época, segundo Febvre e Martin, existia o

\footnotetext{
${ }^{1}$ Fonte: < http://www.spectrumgothic.com.br/gothic/gotico_historico/caligrafia_medieval.htm $>$. Acesso em: 04 nov. 2009
} 
empréstimo dos livros de instituições monásticas que não queria fazer doações às novas bibliotecas.

O Período Laico deu-se do século XIII até o XV. De acordo com os autores, “a característica predominante do novo período [...] é a de os mosteiros deixarem de ser os únicos produtores de livros e só os produzirem para o uso próprio”. Os mosteiros continuaram a copiar diversos manuscritos para uso próprio e essa prática se estendeu até o início do século XVI.

Surgem, nesse período, os copistas profissionais, que ficavam submetidos à fiscalização das universidades. Não eram livres para trabalhar para seu único interesse profissional; estavam a serviço do público.

O livreiro era menos um mercador do que um depositário de livros usados: em razão da sua relativa raridade, os manuscritos, de facto, eram muitas vezes postos à venda, e passavam de mão em mão durante várias gerações de estudantes e professores. Este comércio de livros usados operava-se por intermédio do livreiro, mas, na maior parte das vezes, ele não era senão mandatário do vendedor, e a caução que tivera de pagar para se estabelecer garantia a sua solvência. (FEVRE; MARTIN, 2000, p. 18).

Existia também a figura do estacionário, que cuidava, a serviço da Universidade, do empréstimo de manuscritos dos quais podiam ser feitas cópias de base, o exemplar, em troca de uma remuneração tarifada. Funcionava da seguinte maneira:

O manuscrito de base, o exemplar, era devolvido ao estacionário depois de copiado, e este podia, então, alugá-lo de novo. Este método tinha a grande vantagem de evitar alterações cada vez mais graves, de cópia para cópia, visto que cada uma era feita a partir de um mesmo modelo único. [...] O modelo, o exemplar, emprestado por mediação dos estacionários (também eles habilitados a multiplicar as cópias) aos estudantes desejosos de copiá-lo ou de mandar copiá-lo por copistas assalariados, não era entregue por inteiro, mas em cadernos separados, o que permitia imobilizar por menos tempo o exemplar, que vários copistas podiam copiar simultaneamente. (FEVRE; MARTIN, 2000p. 19). 
Contemporâneo dessa época, o bispo, bibliófilo e monge beneditino inglês Richard Aungerville, mais conhecido como Richard de Bury, foi escritor da obra Philobiblion, de 1344. Segundo Marcelo Rollemberg, na apresentação da edição brasileira, lançada pela Ateliê Editorial, em 2004, essa obra pode ser considerada a primeira publicação a abordar exclusivamente a paixão pelos livros. Escrita por Bury aos 56 anos, foi publicada um ano antes de sua morte e serviu de incentivo à arte que conhecemos hoje como bibliofilia.

Petrarca, contemporâneo de Richard de Bury, chegou a conhecê-lo pessoalmente e dividiam o mesmo amor pelos livros. De acordo com Frieiro (1941, p. 81), Petrarca ficou conhecido como o "pai do humanismo" e também como o “pai da bibliofilia moderna”. Era um "bibliófilo apaixonado [...] comprava ou copiava tudo o que lhe caia ao alcance das mãos”. Durante suas viagens, colecionou manuscritos latinos antigos e, assim, tornou-se um dos maiores estudiosos de Roma Antiga e Grécia Antiga, de seu tempo. A ele se deve a primeira tradução latina de Homero e, em 1345, descobriu pessoalmente a inédita coleção de cartas de Cícero.

O período pré-renascentista caracterizou-se por uma revolução no campo das artes e da literatura; houve uma busca pela razão e pelo humanismo. McMurtrie (1969) contesta a expressão "Idade das Trevas” consolidada por Petrarca, e considera esse período de intensa atividade intelectual. Os eruditos estudavam ativamente não só a literatura cristã, mas também os clássicos latinos.

De acordo com a Araújo (1986, p. 44), “duas novidades de origem chinesa”, o papel e a xilogravura, ajudaram a acelerar o sistema de produção de livros na Europa. Segundo Febvre e Martin (2000, p. 26), “a matéria-prima (o suporte) é cada vez mais raramente preparada nas oficinas que a utilizam”. Os autores referem-se ao preparo do pergaminho. Nessa época já era de conhecimento a fabricação de papel na Espanha, desde o século XII, técnica introduzida pelos árabes. Segundo Mello (1972, p. 100), “o papel começou a ser produzido, na Espanha, em 1154, quando se construiu o primeiro moinho, em Játiva, que inicia a produção com trapos de algodão”.

O autor enfatiza que o "papel chinês só chegou ao Ocidente quase cinco séculos depois de os países do Médio e Extremo Oriente terem dominado a sua fabricação”. O uso do papel não foi logo difundido pela Europa, pois era mais fino e frágil em relação ao pergaminho, e rasgava facilmente. Era utilizado principalmente quando o documento escrito não era destinado a durar, como em cartas e rascunhos. (FEBVRE; MARTIN, 2000, p. 33). 
Diante desse cenário surge a invenção do alemão Johann Gensfleisch Zur Lader, mais conhecido como Gutenberg. Quando vivia na Holanda, por volta de 1448, conheceu o advogado Johann Fust e formaram uma parceria. Segundo Gaudêncio Junior (2004, p. 14), entre “1452 a 1455, Gutenberg e Fust trabalharam arduamente para conclui a famosa 'Bíblia de 42 linhas', supostamente o primeiro registro impresso em tipos móveis em metal”. Um desentendimento entre os dois fez com que Fust abandonasse Gutenberg e o substituísse por Peter Scheffer, este "reconhecidamente um dos grandes mestres da tipografia”.

Há algum tempo já estavam em uso prelos para a impressão de gravuras utilizando a técnica da xilogravura, mas as letras da Bíblia de Gutenberg não foram gravadas em blocos de madeira. Segundo o site Tipógrafos.net, a meta de Gutenberg era criar uma impressão com letras tão belas como as manuscritas. Para tal, escolheu um exemplar manuscrito da biblioteca do mosteiro de Mainz, cuja caligrafia era a letra Textura. A famosa "Bíblia de 42 linhas” é uma obra dividida em dois volumes com 1282 páginas, com 42 linhas cada, e reune o Antigo e o Novo Testamentos. Foram impressos 180 exemplares, dos quais apenas se conservam 48, dois dos quais estão em posse do Gutenberg-Museum, em Mainz. A Biblioteca Nacional do Rio de Janeiro também possui dois exemplares dos dois volumes da Bíblia de Mongúncia.

Figura 2: Volume da Bíblia de Mogúncia da Biblioteca Nacional do

Rio de Janeiro
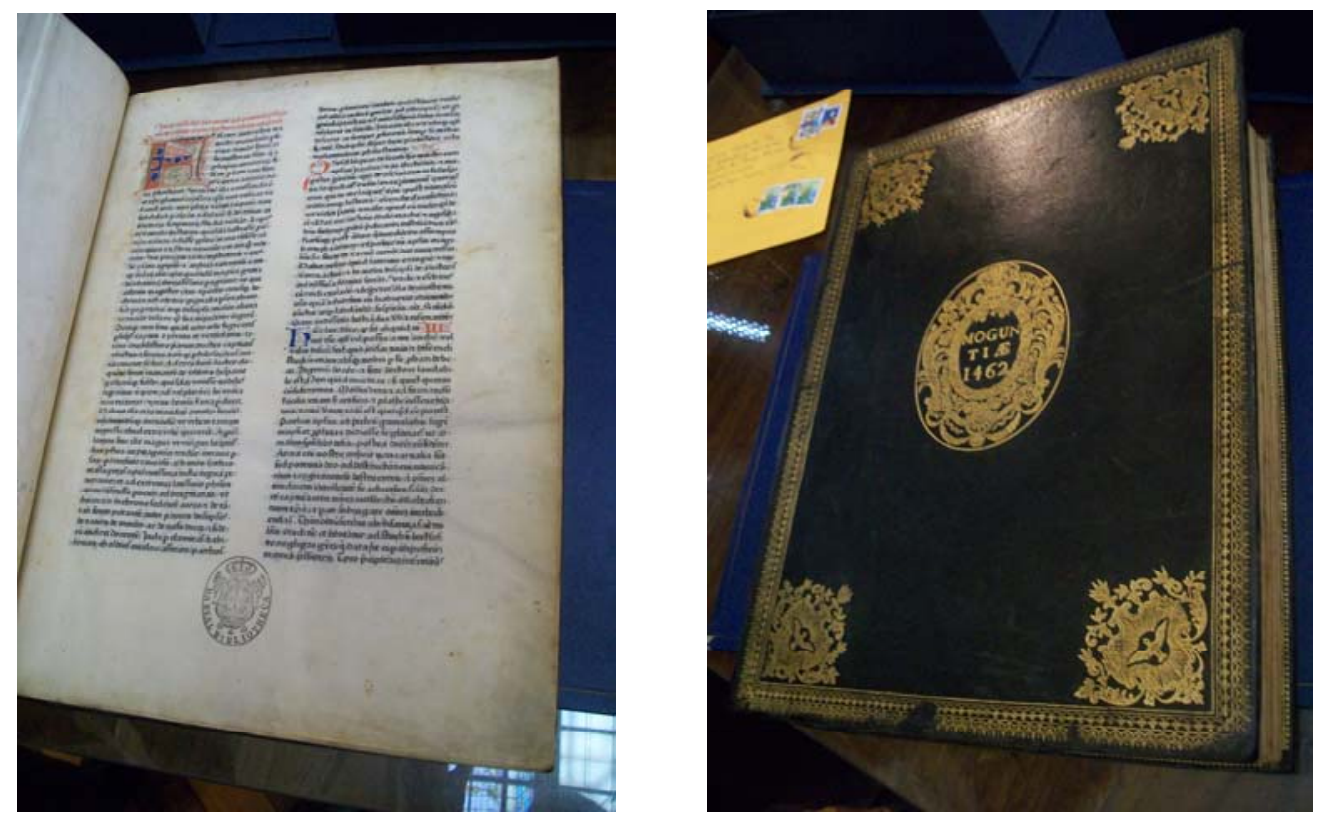
De acordo com Febvre e Martin (2000, p. 102), os incunábulos apresentam exatamente o mesmo aspecto dos manuscritos. Nesse período inicial, os impressores imitavam fielmente a escrita dos manuscritos e utilizavam grupos de letras ligadas entre si pelas mesmas ligaduras da escrita manuscrita. “As iniciais dos livros impressos são rubricadas à mão pelos calígrafos e iluminadas pelos mesmos artistas que trabalham para os manuscritos”. Segundo os autores, um leigo não conseguiria distinguir um livro impresso de um manuscrito.

Segundo Mello (1972, p. 256),

[...] incunábulo, proveniente do latim cuna (berço, origem), caracteriza o livro impresso durante o século da Invenção da Imprensa (XV). Também são considerados incunábulos (tabulares ou xilográficos) os livros editados, embora gravados em madeira, que apareceram antes dos tipográficos, isto é, anteriormente á invenção do tipo móvel.

Por convenção, adotou-se que os livros impressos entre 1455, data aproximada da publicação da Bíblia de Gutenberg, até 1500 recebem o título de incunábulos. Mas, de acordo com Mello, muitas obras importantes de grandes artistas gráficos que nasceram na segunda metade do século XV só foram impressas no século XVI. Essas obras possuem perfeita apresentação gráfica, "sob o ponto de vista artístico, considerando-se texto, ilustrações, iluminura e miniatura, são considerados incunábulos, igualmente os livros surgidos até 1550”.

O autor relata que o termo incunábulo foi utilizado pela primeira vez com relação ao livro impresso, em 1639, pelo Decano da Catedral de Münster, no tratado De ortu et progressu artis typographiae, na Cidade de Colônia. “A obra era comemorativa do segundo centenário do descobrimento do tipo móvel de Gutenberg, período que se estendia até 1500, como prima tipographiae incunabula, isto é, a Tipografia no seu nascimento”.

Para Febvre e Martin (2000), a tipografia tornou os textos mais acessíveis e com uma difusão maior que os manuscritos, mas eram textos que já haviam alcançado êxito enquanto manuscritos. Houve, nessa época, uma seleção do que seria impresso seguindo o critério do que seria mais rentável aos livreiros e impressores. Uma grande maioria 
eram textos em latim, aproximadamente $77 \%$ do total, 7\% em italiano, 5 a $6 \%$ de livros em alemão, 4 e 5\% em francês, e um pouco mais de 1\% em flamenco.

Segundo os autores, eram textos predominantemente religiosos, cerca de $45 \%$ do total, considerando que a maioria dos leitores eram clérigos; depois livros de caráter literário, clássicos, medievais e contemporâneos: cerca de 30\%; e 10\% de livros de direito e livros de caráter científico.

Mello (1972, p. 262) listou as características gerais dos incunábulos:

1. Falta de páginas de rosto, portada ou frontispício. Até 1476, os livros não os apresentavam.

2. Falta de letras capitais no começo dos capítulos ou divisões da obra. É sinal seguro, porque os impressores deixavam em branco o espaço destinado às letras capitais, para que estas fossem desenhadas, posteriormente, e ilustradas a mão pelos miniaturistas, a fim de conseguirem o máximo de semelhança com os manuscritos. Foi este um dos caracteres que mais contribuíram para a falsificação, que eram (sic), muitas vezes, mais valiosas que os impressos. Johann Fust conseguiu vender, em Paris, algumas Bíblias de Mogúncia, que acabavam de ser impressas, como manuscritos. [...]

3. Raridade de divisões em capítulos. O texto era seguido, sem solução de continuidade.

4. Substituição e emprego de certas letras por outras como $c$ por $t$ (initio, Horatio, estão impressas inicio, Horacio. $\mathrm{O} e$ em lugar dos ditongos ae e oe. Uso indistinto de $i$ ou $y, v$ ou $u$, erros resultantes do desconhecimento do latim.

5. Falta parcial ou total dos sinais de pontuação, e forma particular dos mesmos, quando empregados. O ponto tem forma de asterisco ou é quadrado, a vírgula é traço oblíquo da direita para a esquerda.

6. Emprego exagerado de abreviaturas. A finalidade era confundir os livros com os manuscritos, por semelhança, e não como falsificação. Muitos desonestos se aproveitavam dessa preocupação.

7. Falta de paginação e de caracteres arábicos. Nos primeiros impressos, a ausência era absoluta.

8. Largura exagerada das margens.

9. O papel que se usava nas primeiras edições era grosso e defeituoso, e de cor acinzentada ou amarelada. 
10. Irregularidade ou imperfeição dos caracteres. Esta característica é pouco segura e rara, em vista do rápido progresso da Arte Tipográfica.

11. Emprego quase exclusivo do gótico.

Em relação às ilustrações dos primeiros livros impressos, segundo McMurtrie (1965, p. 246), "nem todos os antigos livros impressos foram ilustrados com xilogravuras, pois usaram-se (sic) também, embora raramente, as gravuras abertas em chapas de cobre”. O autor esclarece que nessa época se deu preferência as xilogravuras, pois havia dificuldades em relação ao processo de impressão do livro e da gravura em metal:

[...] a dificuldade estava em que as gravuras de cobre não se imprimiam pelo mesmo processo, ou no mesmo prelo que as formas de tipo. Eram precisas duas impressões completamente independentes para se obter o texto e a gravura na mesma folha, ao passo que o impressor que usava xilogravuras, (sic) conseguia o mesmo resultado com um só movimento da prensa; e com trabalho e apetrechamento dobrado havia ainda dificuldade em assentar a gravura na devida posição em relação ao texto. Devido a esta dificuldade, as primitivas obras com gravuras de metal têm as estampas impressas em folhas soltas intercaladas, ou em papel fino, aparado e colado na devida posição. (MCMURTRIE, 1965, p. 246)

Para Mello (1972, p. 108), com a difusão da impressa pela Europa, a gravura desenvolveu-se e "os mestres da xilogravura são solicitados, constantemente, para gravar tipos e ilustrar livros, e entre eles se destacam grandes pintores e gravadores, como Dürer, Holbein e Van Dick”.

A apresentação atual do livro com página rosto, indicação de autor, indicação de impressão, data, paginação e formato foi se desenvolvendo junto com a indústria do livro. Grandes livreiros, tipógrafos, encadernadores e ilustrações fizeram história, como Aldo Manuzio, Garamond, Estienne, Gryphius, Geofroy Tory, Barbous, Giutis e Didots, com inovações que facilitaram cada vez mais a aceitação do uso do livro impresso. De acordo com Pinheiro (2004),

[...] os séculos XV e XVI viram a adoção do papel de trapos como principal suporte do texto impresso, a introdução da página de rosto, da paginação, do título corrente; a substituição do incipit pelo título da partida e do explicit pelo colofão, da oposição romano/itálico, a imposição de letras ornadas 
(capitais ornamentadas e capitais historiadas) e o surgimento das alíneas, suavizando a página imprensa.

Frieiro (1941, p. 81) comenta que a invenção da imprensa incrementa a arte da bibliofilia. "Na época de Aldo Manuzio principia a voga das encadernações de luxo, que passaram a ser daí em diante a marca distintiva dos verdadeiros bibliófilos”. Como colecionador de encadernações de luxo, Grolier torna-se famoso e é considerado, por isso, cronologicamente, o primeiro bibliófilo, na acepção moderna do termo.

\subsection{História do Livro no Brasil}

Não há como falar de história do livro no Brasil sem mencionar que ela possui uma história conjunta com a de Portugal. Por ter sido colônia portuguesa, o Brasil sofreu censura quanto à impressão de livros, na época. Hallewell (1985, p. 8) afirma que:

[...] pelo menos nos dois primeiros séculos da colonização portuguesa e espanhola a tipografia foi, em toda parte, a auxiliar da Igreja evangelizadora, implantada em quase todos os casos por iniciativa clerical e destinada a maior parte de sua produção às necessidades do clero e das missões.

Somente três séculos depois da invenção da imprensa e da chegada dos portugueses ao Brasil é que se tem notícia da instalação de uma tipografia.

O fato é que não houve prelo no Brasil até que Antônio Isidoro da Fonseca instalasse no Rio de Janeiro uma tipografia em 1747, que chamou de "segunda oficina", querendo significar que possuíra uma primeira em Portugal. De fato, Isidoro da Fonseca era impressor conhecido em Lisboa, onde tinha muitas obras de vulto e autores célebres (MORAES, 2005, p. 154).

O livro impresso por Isidoro da Fonseca em 1747, era um folheto de vinte e duas páginas, intitulado: Relação da entrada que fez o excellentissimo, e reverendissimo senhor D. Fr. Antonio do Desterro Malheyro bispo do Rio de Janeiro, em o primeiro dia deste prezente anno de 1747[...]. Mas a política portuguesa da época era contrária a essa tipo de iniciativa. Não permitia o desenvolvimento de indústrias nas colônias, como medida de prevenção de um possível prejuízo as indústrias da metrópole. 
Por esse motivo que em 6 de julho do ano de 1747 saiu uma provisão endereçada ao governador do Rio de Janeiro mandando fechar a tipografia, apreender o material e remeter tudo para o reino de Portugal. Esse documento dizia que não era conveniente imprimir papéis, pois não era vantagem para os impressores trabalharem no Brasil, onde as despesas seriam maiores que no reino. E que seria conveniente mandar imprimir os livros e papéis em Portugal onde receberia todas as licenças necessárias. (MORAES, 2005, p.71).

Segundo Moraes (2005) nenhuma outra tipografia existiu no Brasil até que a mudança do governo português para o Rio de Janeiro exigiu a instalação de uma imprensa para a publicação dos atos oficiais. Fundou-se, então 13 de maio de 1808, a Imprensa Régia. O governo autorizou a instalação de uma tipografia na Bahia, em 1811, comandada por Manuel da Silva Serva. De 1808 a 1822, essas duas tipografias foram as únicas que funcionaram no Brasil.

A Imprensa Régia tinha por obrigação publicar a documentação oficial do Reino. Era permitido, a tipografia régia imprimir livros de diversos assuntos, mas estes não poderiam ferir a imagem da monarquia.

\footnotetext{
A régia tipografia imprimiu pequenas brochuras, folhetos, opúsculos, sermões, prospectos, obras científicas, literárias, traduções de textos franceses e ingleses versando sobre agricultura, comércio, ciências naturais, matemática, história, economia política, filosofia, teatro, óperas e dramas, romance, oratória sacra, poesia...Vale dizer que foram 720 títulos até 1822, sem contar todas as incontáveis impressões feitas com intuito de comemorar e documentar as festas reais. (SCHWARCZ, 2003, p. 290)
}

De acordo com Moraes (2006, p. 114) depois da proclamação da Independência do Brasil, em 1822, espalham-se pelo país inteiro novas tipografias, primeiramente direcionadas a impressão de jornais. As tipografias das províncias logo começaram a imprimir folhetos e até livros. Segundo o autor a partir daí começa uma nova era para a história do livro no Brasil. 


\section{Capítulo II}

\section{Biblioteconomia de Livros Raros}

Prado (1992), em seu livro-manual sobre organização e administração de bibliotecas, fala de forma clara e sucinta sobre os objetivos gerais de uma biblioteca. Segundo a autora, existem dois aspectos básicos a se considerar quanto à organização de uma biblioteca: um é o intelectual, que diz respeito à "preocupação de servir a um público que pede conhecimentos, podendo esse público ser ou não especializado”; e o outro aspecto é o material, que "é a preparação técnica do acervo para que fique em condições de atender rápida e acertadamente às consultas dos leitores”.

A Biblioteconomia de livros raros e de coleções especiais, por ser uma especialidade da ciência biblioteconômica, não difere em muito da Biblioteconomia exercida em bibliotecas convencionais. Bibliotecas que possuem coleções de livros raros e preciosos também necessitam de uma política de desenvolvimento de acervo, possuem serviços de atendimento ao usuário, com o diferencial de que os itens só podem ser consultados, não sendo permitido empréstimo domiciliar. Exigem uma maior segurança do acervo, por se tratar de obras que possuem uma importância para a memória do conhecimento registrado pela humanidade.

Segundo Archer (1965, p. 1), durante as décadas de 1940 e 1950, os problemas em relação aos cuidados, de materiais incomuns, nas salas de livros raros e coleções especiais em faculdades, universidades e bibliotecas particulares causaram preocupação crescente entre os bibliotecários e administradores. A quantidade de livros raros, panfletos e manuscritos adicionados às presentes bibliotecas aumentou ainda mais as dúvidas em relação ao tratamento direcionado a essas obras. Já em 1941, G. Flint Purdy manifestou interesse em problemas de investigação e conservação dos materiais de biblioteca. Seu apelo dizia que escolas de Biblioteconomia e as revistas da área estavam negligenciando a função da conservação e dando muita ênfase à disseminação do conhecimento através dos livros, resultando na negligência indevida da preservação do conhecimento que estão nos livros.

Archer cita ainda a fala do Dr. Pierce Butler, da Universidade de Chicago, em 1943, durante uma classe da Graduate Library School, que dizia que a administração do 
setor de livros raros é um ramo da Biblioteconomia que, não tanto quanto sabemos, desenvolveu nenhuma literatura. É um crescimento sem planejamento. Na América se desenvolveu de forma pragmática, mesmo às cegas. A uniformidade com o que existe surgiu por imitação, valendo mais que literatura.

Nota-se que esse quadro de quase 70 anos atrás pouco mudou. A literatura desenvolvida, tanto no Brasil como fora, sobre Biblioteconomia de livros raros é mínima, mas é de grande valia para os profissionais da área. A queixa maior dos estudiosos desse tema é que escolas de Biblioteconomia estão dando mais ênfase aos avanços tecnológicos, tentando transformar bibliotecas convencionais em bibliotecas virtuais, esquecendo da importância histórica e cultural de acervos antigos.

\title{
2.1 Conceitos de livro raro
}

O conceito de livro raro é um dos grandes assuntos tratados na literatura brasileira. Segundo Carteri (2005), não existe

\begin{abstract}
[...] uma política norteadora da área de raridade bibliográfica que padronize o tratamento dispensado ao livro raro, havendo inclusive divergências sobre a própria determinação de raridade. Diferentes instituições adotam procedimentos diversos no tratamento dos mesmos livros, revelando não apenas a divergência que há na área, como também ausência de diálogo eficaz entre os envolvidos na mesma. Infelizmente, além de confundir o leitor leigo, tais disparidades prejudicam a atuação dos próprios profissionais.
\end{abstract}

Em uma biblioteca que possua uma coleção de obras raras, grande parte do acervo é composto de livros raros. Apesar do conceito de obra rara remeter a livros, segundo Sant’Ana (2001), esta coleção pode incluir periódicos, mapas, folhas volantes, cartões-postais e outros materiais impressos. De acordo com o autor, fotografias, gravuras e desenhos são obras únicas e originais e, portanto, não recebem esta denominação de obra rara.

Segundo Nathanson e Vogt-O’Connor (1993), a definição tradicional de livro raro é qualquer livro que tem um valor considerável; isso quando a demanda para o livro for superior à oferta, geralmente devido à sua importância, à escassez, à idade, às condições físicas, à estética e às propriedades, à associação ou ao assunto. Se não há demanda para um livro, não vai ser comprovadamente um livro raro, mesmo se os 
outros fatores existem. Ele pode ter um pequeno valor ou nenhum, se ninguém o quiser. Esta demanda pode se alterar com o tempo, de acordo com a mudança de interesses.

A literatura brasileira sobre livros raros remete sempre a dois grandes estudiosos do tema: Ana Virgínia Pinheiro e Rubens Borba de Moraes, sendo eles bibliotecários e especialistas na área.

Para Moraes (2005, p. 67), o que faz um livro ser considerado raro é a procura por ele: “O valor de um livro nada tem que ver com sua idade. A procura é que torna um livro valioso. O que o torna procurado é ser desejado por muita gente, e o que o fez desejado é um conjunto de fatores, de particularidades inerentes à obra”. Essas particularidades foram abordadas pelo autor, no seu livro O bibliófilo aprendiz, uma espécie de manual para bibliófilos, mas de grande valia para leigos. São as seguintes as particularidades a serem observadas:

- "Livros procurados, cuja existência é sabida, mas de que nunca ninguém viu um exemplar”, diz respeito a livros referenciados em célebres bibliografias, como Brunet, Inocêncio, Barbosa Marchado;

- “O livro antigo é uma mercadoria internacional, seu preço é regulado em moeda forte” (p. 31), “de fato, o livro bom, a edição rara, é uma mercadoria de valor internacional” (p. 45);

- A primeira edição de uma obra célebre;

- "Muitas vezes um livro é procurado porque foi impresso por um tipógrafo célebre, porque contém ilustrações feitas por um ilustrador conhecido, porque está revestido de uma encadernação feita por um encadernador famoso e muitas vezes até porque contém um erro de impressão divertido” (p. 67);

- Procedência de um livro, origem e a quem pertenceu;

- Anotações, assinaturas, encadernações com brasão, dedicatória do autor ou de uma personalidade;

- Ex libris de colecionador famoso;

- Se a obra foi citada em grandes bibliografias, como Maggs Bros, Brunet, Graesse, Barbosa Machado ou Inocêncio;

- Obras censuradas;

- Primeiro livro sobre um assunto;

- Primeiro livro sobre um país ou uma cidade; 
- No caso do Brasil, se pertence à brasiliana ou - como o autor chamou - à brasiliense;

- “O valor de um livro antigo depende do estado em que se encontra, da encadernação que o veste ou de alguma particularidade que o exemplar apresenta” (p. 85).

Já para Pinheiro (1989), raridade bibliográfica está muito ligada, primeiramente, ao caráter artesanal da obra. A autora confirma a idéia de que só a antiguidade de uma obra não caracteriza a sua raridade. Está muito ligada aos aspectos bibliológicos, por exemplo: inexistência à evolução da página de rosto, colofão, título de partida e título corrente, licenças e disposições do texto, colunas, corandel, assinaturas, etc.

Além desses detalhes técnicos e bibliológicos, a autora destaca a importância de se distinguir entre raro, precioso e único:

Raro: é aquilo que é tratado sob esta acepção em qualquer lugar - o que é raro no Brasil, também o é na América do Norte, na Europa, na Ásia.

Único: remete à idéia de "exemplar único conhecido", relevando-se a existência de acervos potencialmente raros, não identificados, em bibliotecas, arquivos e museus, guardiães de livros. Quando se identifica um exemplar, não se pode ter a certeza de que ele seja efetivamente um exemplar único, no mundo.

Precioso ou de raridade relativa: abrange as noções de posse e identidade. Cada curador de acervo deve encarregar-se de acumular aquelas coleções que, em princípio, seriam da sua exclusiva competência, em função da missão da pessoa (física ou jurídica) que representa. Por exemplo: compete ao bibliotecário de um banco captar e armazenar todos os títulos referentes à história daquele banco, de seus fundadores, de seus acionistas - que são, por isso, preciosos; compete à determinada biblioteca estadual captar todos os itens referentes ao estado que representa (autores naturais, obras locais, obras sobre o estado etc.), formando uma coleção exaustivamente personalista e, por isso, preciosa (PINHEIRO, 2004).

Segundo Pinheiro (2004), compete ao bibliotecário, curador ou “dono” do acervo determinar e avaliar os critérios de raridade de seus itens, como também formalizar a metodologia adotada. Nos anos 1980, Ana Virginia Pinheiro dedicou-se ao levantamento de critérios adotados por instituições públicas e privadas com o objetivo de delinear os conceitos de raridade e preciosidade bibliográfica, “não universais, mas 
aceitos universalmente, e associar ao caráter de unicidade, atribuído ao livro” (PINHEIRO, 1989, p. 21). Esse estudo gerou uma metodologia para critérios que podem ou não se adotados e envolvem, principalmente:

- Limite histórico;

- Aspectos bibliológicos;

- Valor cultural;

- Pesquisa bibliográfica;

- Características do exemplar.

Segundo a autora, de "todos os critérios para estabelecimento de raridade bibliográfica propostos, o limite histórico e os aspectos bibliológicos são supervalorizados em detrimento dos demais. Nas bibliotecas, um livro é raro porque é antigo ou belo” (PINHEIRO, 2004).

Já em seu texto, Sant’Ana (2001) diz que existem padrões aceitos internacionalmente de raridade bibliográfica, como o de que todos os livros impressos artesanalmente são considerados raros e que existe uma data limite para esse tipo de produção que é o ano de 1801. Segundo o autor, essa data foi escolhida, pois, desde a invenção da tipografia, os livros vêm sofrendo aperfeiçoamentos durante três séculos e só no início do século XIX, com a invenção da "máquina de fabricar papéis de Nicolas Robert, aperfeiçoada por Fourdrinier em 1803”, o uso de rotativas de impressão off-set e o linotipo, a substituição do uso de papel de trapos por papel de polpa de madeira e as reproduções fotomecânicas de ilustrações, passaram então a automatizar a produção de livros e a desvalorizá-los também.

\subsection{Desenvolvimento e formação de acervos de livros raros}

Para Vergueiro (1989), desenvolvimento de coleções é um trabalho de planejamento que exige comprometimento com metodologias. "O tipo de biblioteca, os objetivos específicos que cada uma delas busca atingir, a comunidade específica a ser atendida” influenciam no desenvolvimento da coleção. Para o autor, atividades que são parte do processo de desenvolvimento de coleções, como avaliação, estudo da comunidade, políticas de seleção, desbastamento, aquisição e seleção, devem fazer parte da rotina da biblioteca como fazem as atividades de processamento técnico (catalogação, classificação e indexação). 
Por isso é interessante que se formalize essas atividades, com o propósito de garantir a sua continuidade, elaborando uma política de formação e desenvolvimento de acervo. Segundo Vergueiro (1989, p. 25),

[...] trata-se de tornar público, expressamente, o relacionamento entre o desenvolvimento da coleção e os objetivos da instituição a que esta coleção deve servir, tanto por causa da necessidade de um guia prático na seleção diária de itens, como devido ao fato de ser tal documento uma peça-chave para o planejamento em larga escala.

No caso de uma coleção de livros raros, além de formalizar atividades de rotina, a política de formação e desenvolvimento de coleções, segundo Ogden (1997 apud Pinheiro, 2004), registra a

[...] singularidade do acervo, importância científica e cultural e valor permanente das coleções. A linha de acervo consiste na definição de conteúdos dos itens e formatos que podem ser incorporados, atendendo aos objetivos institucionais. Os acervos resultantes organizam-se em coleções de origens múltiplas, integradas ou não.

Para Pinheiro (2004), a escolha de ações de preservação e de organização, na Biblioteconomia de livros raros, deve refletir na política e nas linhas de acervo. “A falta dessas definições leva ao colecionismo mórbido e nostálgico, onde tudo deve ser guardado e nada pode ser subtraído, desencadeando o inevitável colapso da biblioteca como organismo vivo que é”.

\subsubsection{Aquisição de livro raro}

Muitas vezes uma coleção de livros raros é formada por compra de bibliotecas de colecionadores ou doação de pessoas célebres, como foi o caso da coleção Thereza Christina, que pertenceu ao Imperador Dom Pedro II e está armazenada, em grande parte, na Biblioteca Nacional do Rio de Janeiro. Mas também pode ocorrer como nas coleções de livros e manuscritos raros das bibliotecas de universidades norteamericanas, nas quais a intenção, no começo dos séculos XVII e XVIII, era apenas formar uma biblioteca de consulta para os estudantes. Segundo Wolf (1965), essas bibliotecas adquiriram livros que agora são considerados raros; foi devido à passagem do tempo e à ampliação da definição de livro raro. 
A biblioteca que possui uma verba disponível pra isso pode adquirir coleções em antiquários especializados em coleções de livros, ou em leilões. Segundo Cave (1976), a venda de livros em leilões foi introduzida na Inglaterra, no século XVII, com a venda da Biblioteca de Lázaro Seaman, em novembro de 1676. Não demorou muito tempo, após a introdução do método de leilão público, para que os especialistas na venda de livros por esse método aparecessem. Os resultados de leilões geram os catálogos de vendas; esses têm uma real importância como obras de referência para os especialistas, que, muitas vezes, são chamados para avaliar coleções já existentes nas bibliotecas.

Outra maneira de aquisição de livros raros é por doação. De acordo com Cave (1976), existem vários tipos de doações de livros raros: pode ser uma simples doação direta pelo proprietário do livro à biblioteca ou a doação em dinheiro para a compra de um livro em particular. Segundo o autor, existem outras duas formas bem específicas; chamou-as de doação às escondidas e doação virtual.

A doação às escondidas consiste no seguinte: a uma biblioteca é dada a oportunidade de comprar uma coleção completa, ou escolher livros dessa, a um preço consideravelmente mais baixo que o proprietário sabe que poderia obter no mercado aberto. Já doação virtual acontece quando os proprietários, sem entregar a posse legal do material, irão depositá-lo em uma biblioteca e torná-lo disponível, em geral para consulta acadêmica. Para o proprietário é vantajoso, pois não terá que arcar com os custos de manutenção de um acervo valioso. A longo prazo, o material depositado acabará sendo considerada propriedade da biblioteca.

Sant’Ana (2001, p. 5), em seu artigo, mostra a perspectiva sobre aquisição de livros raros no Brasil. Segundo ele, falta uma política consistente de aquisição de obras raras pelas bibliotecas brasileiras.

Embora algumas instituições (em geral, bibliotecas universitárias) tenham adquirido nos últimos anos grandes coleções de livros de bibliófilos já falecidos (na sua maioria antigos pesquisadores ou professores), a compra de exemplares específicos em leilões ou livrarias especializadas é feita quase exclusivamente por colecionadores.

Estas bibliotecas adquirem as coleções pelo seu valor de conjunto, ou seja, mais pela possibilidade de criar novas áreas de pesquisa do que pela importância de alguma obra em particular. Deste modo, a compra de obras raras fica quase sempre condicionada à presença ou não dentro das coleções. 
Outra perspectiva para a aquisição de livros raros e que pode ser uma solução para instituições brasileiras é a aquisição cooperativa. Segundo Gauz (2006), trata-se da compra de livros, em parceria, por instituições. Surgiu em 1995, quando:

[...] um professor da University of Notre Dame viu um manuscrito com anotações musicais do ano de 1300, aproximadamente, ser anunciado num catálogo de livreiro alemão. O professor ligou para Paul Saenger, curador de livros raros e manuscritos da Newberry Library, para saber se essa biblioteca compraria o manuscrito. Saenger, então, conta que teve a idéia de propor uma parceria, na qual a universidade arcaria com um terço do valor do livro, que ficaria na Newberry Library, mas também passaria uns meses na universidade. O professor era Kent Emery, uma autoridade em estudos medievais, que imediatamente concordou com a sugestão (eles acabaram comprando um outro exemplar, quase idêntico, devido à demora na resolução de questões legais).

A vantagem desse tipo de aquisição é que se preserva a memória bibliográfica de um país ou de uma cidade dentro de seu território, evitando assim que coleções sejam dispersas, ou compradas por outros países.

\subsubsection{Organização da coleção}

Segundo Pinheiro (2004), desde a famosa

[...] Biblioteca de Alexandria, as bibliotecas eram organizadas por proveniência, as coleções eram arranjadas segundo o colecionador original, sem qualquer possibilidade de descarte; até que, em meados do século XVIII, esse hábito foi abandonado e se organizou a biblioteca por assuntos, integrando-se as coleções. No entanto, a continuada aquisição de coleções de livros raros e a ocorrência de títulos dobrados provocaram a segmentação da biblioteca por datas, determinada mais em função do espaço disponível para armazenamento do que pela História do livro.

A organização de livros em bibliotecas, normalmente, depende de suas características de assunto, data, autoridade, formato, de forma que sejam acessíveis para fins de estudo e pesquisa. Segundo Baughman (1965), o leitor potencial é habilitado para ir diretamente às prateleiras de modo a consultar os materiais de que necessita, onde, pelo menos em teoria, ele também vai encontrar, na mesma prateleira ou próximo 
à mão, outros textos que estão relacionados ao seu interesse. Para o autor, no caso de livros raros especialmente, os elementos que merecem prioridade podem ter pouco ou nada a ver com o conteúdo textual. Alguma peculiaridade ou particularidade da questão, por exemplo, ou alguma característica específica de proveniência, de condição física, e assim por diante, pode dar interesse singular para o representante de uma edição de outra forma ordinária. Em tais casos, normais métodos de classificação de assunto raramente são suficientes e o bibliotecário é confrontado com a responsabilidade de determinar quais características devem ser enfatizadas.

De acordo com o autor, a primeira decisão a ser tomada quando se tem uma coleção recém-adquirida é se essa será mantida como uma unidade intacta, ou se deve ser misturada com os outros livros, sendo classificada de acordo com a norma da biblioteca. Para Baughman, a fonte maior de preocupação é se essa coleção chegou por doação ou por compra. Se ela veio por doação, os termos em que foi aceita se tornam primordiais e devem ser honrados, e estes podem estipular uma cobrança a ser preservada. Mas se, por outro lado, não houve estipulação de termos de cobrança, ou se a coleção foi comprada com fundos institucionais, o bibliotecário deve se sentir completamente livre para organizá-la de forma lógica e eficiente; mas tendo o cuidado de saber que a possibilidade de dispersão pode destruir algo que não será mais recuperado.

Baughman levanta a questão sobre a importância da existência de uma sala especial para os livros raros. Segundo ele, a divisão de livros raros deve ter a sua própria sala de leitura, onde seus livros são consultados, sob vigilância, e que não há acesso ou consulta às prateleiras por leitores. Os livros devem ser retirados das estantes e devolvidos aos seus lugares, após o uso, por atendentes da divisão de livros raros. Para ele, se estas disposições básicas não forem feitas, não há motivo válido para ter uma divisão de livros raros. Deve considerar-se, ainda, a existência de um catálogo adequado dos livros raros, completo, com todos os detalhes necessários, assunto e remissivas. Com estes fundamentos previstos, as vantagens de ter os livros classificados por assunto podem ser secundárias.

Pinheiro (2007, p. 33-35) confirma essa idéia quando fala sobre sistema de localização fixa: 
[...] localização fixa enumera de modo primário ou alternativo todos os itens da biblioteca, a partir de uma notação-base - uma seqüência lógica, com números, letras ou outros sinais, separados por vírgulas e/ou travessões, sem espaços, que identifica o ponto de acomodação do item na área de armazenamento. [...] Cada notação expressa, pelo menos, a estante, a prateleira e o ponto seqüencial numérico de acomodação do item, em determinada área de armazenamento.

Segundo a autora, esse sistema é recomendado à aplicação em "bibliotecas onde a conservação do livro é condição para a salvaguarda de seu conteúdo, porque os livros são organizados segundo a sua materialidade”. Também é muito utilizado por ter a vantagem de favorecer a longevidade dos itens, pois considera a tipologia, os formatos e o suporte dos documentos; por exemplo:

Documentos em suporte de papel (manuscritos, impressos) e em materiais distintos (couro, tecido, pergaminho, fitas magnéticas, discos) não devem ser acomodados lado a lado - o armazenamento diferenciado, conforme a natureza dos materiais e a tipologia documental devem ser consideradas. (PINHEIRO, 2007, p. 52)

Esse tipo de notação para a armazenagem de livros na estante é mais recomendado quando existe um acesso restrito às estantes, como acontece em uma divisão de livros raros, pois, se forem de acesso livre, é provável que toda a organização seja perdida pela displicência do usuário da biblioteca.

\subsubsection{Catalogação de livros raros}

Segundo Mey (1995, p. 6), catalogação é diferente de inventário e listagem de livros, pois “não apenas caracteriza os itens, individualizando-os, tornando-os únicos entre os demais”, mas também os reúne por suas semelhanças.

Para Pinheiro (1990, p. 47),

[...] se a catalogação de um impresso moderno pode provocar incertezas e problemas, o ordenamento complexo e a descrição detalhada de um livro ou periódico antigo e/ou raro, nos moldes estabelecidos pelos códigos e manuais técnicos importados, pode estabelecer verdadeiras barreiras às iniciativas pessoais, considerando, também, as deficiências na formação do 
Bibliotecário, pela ênfase dada nas Escolas de Biblioteconomia às disciplinas de conotação metodológica, em detrimento às da área cultural.

De acordo com Sant’Ana (2001), existem várias normas internacionais de catalogação de livros raros, como a $\operatorname{ISBD(A),~a~segunda~edição~das~Anglo-American~}$ Cataloging Rules (AACR2), e o Descriptive Cataloging of Rare Books (DCRB).

O ISBD (A), ou International Standard Bibliographic Description for Older Monographic Publications (Antiquarian), é uma das extensões do ISBD (International Standard Bibliographic Description), ou, em português, Descrição Bibliográfica Internacional Normalizada. De acordo com Mey (1995, p. 43), “descrição bibliográfica é a representação sintética e codificada das características de um item, de forma a tornálo único entre os demais”.

Segundo a apresentação do ISBD (A), as bibliotecas que possuem livros antigos têm a necessidade de descrever seus itens de forma que eles possam ser claramente distinguidos, para efeitos de comparação com outras cópias e outras edições da mesma obra. Não é objetivo dos bibliotecários de livros raros só a descrição de itens antigos, mas destacar os pontos que distinguem edições.

O ISBD (A) considera como publicações monográficas antigas aquelas produzidas antes da introdução da máquina de impressão, no século XIX, e incluem aquelas publicações de distribuição limitada ou vendidas sob demanda. Esta norma também pode ser utilizada para descrições de publicações posteriores àquelas produzidas à mão que tenham um caráter artesanal. Apresenta recomendação de fazer a descrição de características próprias de livros publicados até século XVIII como colofão, reclamo, assinaturas, paginação, ausência de título e página de rosto, pois, a partir do século XIX, os livros tornaram-se mais padronizados por causa do uso da máquina de impressão.

O manual de catalogação para livros raros da Library of Congress é o Descriptive Cataloging of Rare Books (DCRB). Foi editado em 1981, sendo a versão disponível na internet do ano de 2001. Foi criado para servir de complemento ao AACR2 como norma de catalogação de obras raras. Santa’Ana (2001) destaca que a Library of Congress aplica essa norma para livros publicados antes de 1801 e, para publicações posteriores, aplica o AACR2. Desde a sua primeira publicação o DCRB sofreu atualizações para se adaptar às regras do ISBD (A). 
Segundo Santa'Ana (2001), o DCRB possui um suplemento, o Examples to Accompnay Descriptive Cataloging of Rare Books, que foi publicado pela Bibliographic Standards Commitee of the Rare Books and Manuscripts Section da ACRL/ALA, em Chicago, em 1993. O autor destaca que entre os exemplos estão algumas obras dos séculos XIX e XX, e que servem de demonstração de como proceder com essas obras.

\subsection{Bibliotecários de livros raros}

Sobre os profissionais que trabalham com esses itens que requerem uma formação especializada, Pinheiro (1990, p. 48) destaca a importância do aperfeiçoamento da

[...] formação histórica e crítica (cultural) e técnica e profissional (bibliográfica e biblioteconômica), em vista da natureza do documento a ser tratado e da sua importância para a memória nacional; [...] promover a especialização de estudos em áreas afins e/ou específicas, de modo a cada vez mais minuciar serviços e procedimentos; conscientizar sobre a necessidade de formação e de integração de equipes interdisciplinares e multidisciplinares, que incluam, entre outros: bibliotecários, arquivistas, museólogos, historiadores, especialistas em letras e lingüística, restauradores, juristas, paleógrafos, encadernadores, historiadores da arte, químicos, biólogos, sanitaristas, administradores, engenheiros, arquitetos, bibliófilos, livreiros, editores, etc.

Gauz (2006) lista as qualificações básicas que um bibliotecário de livros raros deve ter:

1. Conhecimento de Bibliografia Descritiva, ou seja, saber como os cadernos de um livro artesanal são formados (até aproximadamente 1820 os livros ainda não eram fabricados de maneira industrial), a posição das linhas d’água e sua importância para a determinação do formato do livro, assinaturas, estilos de encadernação, etc.;

2. Conhecimento de obras de referência para fontes primárias;

3. Conhecimento da coleção;

4. Noções de preservação;

5. Domínio de línguas. 
Para completar a qualificação desses profissionais, segundo a autora, não poderiam faltar conhecimentos de preservação de novas mídias digitais e direito autoral. Ela comenta que profissionais desse tipo são escassos, e cita o exemplo dos Estados Unidos. Mesmo em um “país desenvolvido”, essa especialidade é pouco explorada. Existe uma escola de livros raros, a Rare Book School, criada desde o início de anos 1980.

A Rare Book School, segundo o site, é uma organização independente sem fins lucrativos, funciona como um instituto educacional de apoio ao estudo da história do livro e assuntos relacionados. Foi fundada em 1983 e, desde 1992, tem sede na Universidade da Virgínia, nos Estados Unidos. A RBS oferece bolsas de estudos desde 2001, e os processos seletivos são anuais. Atua em diversos estados, como a Califórnia.

Existem escolas em várias partes do mundo que oferecem cursos de extensão, como a London Rare Book School, que é administrada pelo Centre of Manuscript and Print Studies do Institute of English Studies da Universidade de Londres, e a California Rare Book.

Muitos profissionais estão formando grupos sobre o tema livro raro. Nos Estados Unidos existe o grupo Rare Books and Manuscripts Section (RBMS), da Association of College and Libraries (ACRL), uma divisão da American Library Association. Segundo o site, pretende representar os bibliotecários, curadores e outros especialistas preocupados com aquisição, organização, segurança, preservação, administração e uso de coleções especiais, incluindo livros raros , manuscritos, arquivos e música. Prepara bibliotecas de coleções especiais e bibliotecários para melhor servirem às necessidades dos usuários. É responsável pela publicação do periódico RBM: A journal of rare books, Manuscripts, and Cultural Heritage.

No Brasil existe o Grupo de Estudos Interdisciplinares da Raridade Documental, o GEIRD; segundo Andrade e Cantalino (2007), esse grupo “nasceu da iniciativa de pesquisadores e profissionais da informação baianos preocupados com a identificação e o processamento técnico de acervos especiais, para garantir salvaguarda desses documentos”. Eles estão preocupados com questões epistemológicas em relação ao conceito de livro raro e também procuram difundir “questões teóricas e práticas relacionadas ao trato com documentos preciosos”, como o tratamento técnico dessas obras e "o cultivo de uma atitude de reconhecimento e participação responsável quanto ao destino de nossa memória cultural”. Promovem cursos, debates e seminários sobre o tema. 
É interessante notar que iniciativas desse tipo só engrandecem a bibliografia brasileira sobre Biblioteconomia de livros raros. Seus conceitos precisam ser bem delimitados pelas instituições e profissionais que lidam com essas obras, pois é grande a responsabilidade de salvaguardar o patrimônio histórico e cultural de um país. 


\section{Capítulo III}

\section{Preservação de livros raros}

O bibliotecário Shiyali Ramamritam Raganathan, em 1931, instituiu as “cinco leis da biblioteconomia”, que com simplicidade estabelecem a relação bibliotecárioleitor-livro. De acordo com a primeira lei de Ranganthan, “os livros são para serem usados”, ou seja, o livro é um meio que impulsiona o conhecimento. As coleções especiais e livros raros, por serem muitas vezes coleções que exigem uma atenção técnica mais detalhada com normas de descrição bibliográfica diferenciada, um cuidado maior com a conservação e segurança do acervo, podem, muitas vezes, passar a impressão de que são intocáveis. Isso não é necessariamente uma verdade, pois esses livros são assim tratados para facilitar a preservação da informação e o acesso ao leitor.

\subsection{Conceitos}

Segundo Gameiro (1988 apud Valle, 1991), a “preocupação em conservar vem do princípio da civilização. Muitos documentos foram encontrados em perfeito estado, guardados em lugar seco, para que pudessem ser conservados por muitos séculos”. Valle (1991) comenta que, no início, os procedimentos eram experimentais e muitas vezes causavam danos aos documentos. Depois é que os processos de restauração passaram a se basear em princípios científicos.

Para Zuñiga (2002), “preservação é entendida de forma extremamente abrangente, compreendendo todas as ações desenvolvidas pela instituição visando a retardar a deterioração e possibilitar o pleno uso a todos os documentos sob sua custodia”.

De acordo com Valle (1991), “a preservação é objetivo fim”, é o que se deseja alcançar com outras duas atividades, a conservação e a restauração, que são meios para se atingir a finalidade maior. Guimarães (2007) acompanha o mesmo raciocínio de Valle: “a preservação seria, na verdade, o estabelecimento de uma política geral e, a partir dessa política, então planejar as outras duas áreas, a de conservação preventiva e a de restauração”. 
A conservação diz respeito mais às atividades preventivas, preserva a integridade física dos documentos. Hoje em dia o termo mais utilizado é conservação preventiva, que, segundo Zuñiga, "é o conjunto de ações que visam a prevenir os danos sofridos pelo acervo como um todo, minimizando a deterioração dos documentos”. Sua aceitação sofreu restrições por ser considerada como uma atividade de rotina que poderia ser exercida por qualquer pessoa sem qualificação específica.

Para Ogden (2001a, p. 11), as ações de conservação que ela chama de preservação preventiva desempenham "em relação aos materiais de biblioteca e de arquivo, basicamente o mesmo papel da medicina preventiva e da saúde pública em relação ao ser humano”. Segundo ela, são ações de rotina da biblioteca, tais como: aquisição, encadernação, processamento de materiais impressos e não impressos, colocação nas estantes, circulação, reprodução do acervo, pequenos reparos e impedimento de acesso. Para a autora, dentro de um programa de preservação, um sistema de controle climático é o componente mais importante, pois esse "é capaz de fornecer um ambiente estável durante o dia e a noite, e ao longo do ano”.

Já a restauração, que, no começo do século XX era considerada a principal atividade de preservação, hoje em dia é condenada e considerada muitas vezes a última coisa a ser feita. Segundo Valle (1991, p.110),

[...] a restauração é uma etapa importante e necessária, mas deve ser feita somente em casos extremos e o objetivo de um planejamento para a preservação é evitar-se que seja feita a restauração. E políticas com o estabelecimento de critérios é a melhor forma de se atingir este objetivo. Isto não significa que a atividade de restauração não tenha seu mérito e não seja necessária em alguns casos, devolvendo documentos inutilizados à sua condição de uso.

O conceito de preservação, na literatura, muitas vezes discutido e questionado, reflete a importância dada ao patrimônio histórico, artístico e cultural da humanidade. O que preservar é uma decisão que cabe à administração e aos técnicos, com a ajuda dos usuários das obras. Também exige conhecimento histórico, técnico e filosófico do objeto.

De acordo com Silva (1998), preservação é “toda ação que se destina a salvaguardar ou a recuperar as condições físicas e proporcionar permanência aos materiais dos suportes que contêm a informação”. 
Já para Hazen (2001, p.7), “a preservação ocupa posição de destaque entre os principais problemas dos bibliotecários. A questão incorpora elementos de alcance e magnitude, custos, psicologia, logística, tecnologia, organização, ética, filosofia e administração”. Para o autor, a preservação deve estar diretamente ligada ao desenvolvimento, gerenciamento das coleções e aos bibliotecários. Critica a literatura sobre preservação, pois, segundo ele, a mesma faz uso de

[...] idiomas altamente técnicos de estresses físicos e tolerâncias, de reações químicas e fotoquímicas. O vocabulário é repleto de termos como níveis de $\mathrm{pH}$, degradação molecular, faixas de sensibilidade fotoquímica, hidrólise ácida e desacidificação em fase gasosa. Considerando-se o valor nominal, esta literatura sugere que a preservação é propriamente, e exclusivamente, o campo de trabalho de químicos, físicos e de cientistas e técnicos de mentalidade semelhante. (HAZEN, 2001, p. 7)

Hazen (2001, p. 8), ao falar da natureza da preservação, divide-a em três tipos principais de atividades:

- Tipo 1: “concentra-se nos ambientes de biblioteca e nas maneiras de torná-los mais apropriados a seus conteúdos”. É a preservação no âmbito do gerenciamento de coleções; a chamada política de preservação;

- Tipo 2: “incorpora esforços para estender a vida física de documentos através de métodos como desacidificação, restauração e encadernação”. É a preservação que visa a dar longa vida aos suportes da informação, realizada por especialistas;

- Tipo 3: "envolve a transferência de conteúdo intelectual ou informativo de um formato ou matriz para outro”. É a preservação da informação, cujo objetivo final é a garantia de acesso a informação pelo leitor.

Segundo o autor, essas três categorias envolvem as melhorias ambientais, como controle de temperatura e umidade, que incluem atividades de preservação em larga escala como políticas de circulação, práticas de encadernação, medidas de segurança contra roubo e incêndios e as escolhas de itens individuais que terão um tratamento mais pontual devido à fragilidade do suporte.

As escolhas de atividades que serão desenvolvidas nos três tipos de preservação são dividas em dois tipos de decisões: as para preservação em massa e as decisões de preservação item-por-item. Essas serão tomadas pelo gerente da coleção, que, na maioria das situações, é o bibliotecário, com a ajuda de especialistas. 
A preservação em massa envolve decisões de gerenciamento de coleções e o controle ambiental. De acordo com Hazen (2001, p. 17), “políticas que afetam massas de material eliminam a necessidade de escolha entre itens específicos e são, portanto, relativamente fáceis de formular e executar”. Aplica-se apenas a decisões que afetam igualmente todos os materiais, como a compra de aparelho de ar condicionado, ou a higienização obrigatória de itens que serão incorporados ao acervo.

Já a preservação item-por-item envolve escolhas do tipo “o que será preservado e o que se permitirá que deteriore”. Segundo Hazen, essas escolhas específicas podem ser tomadas de acordo com decisões que afetam o desenvolvimento de coleções, e com ajuda de conhecimento especializado sobre a identificação e preservação de itens.

Os especialistas da preservação são os mais indicados para identificar os materiais em risco de extinção dentro de uma coleção particular, mas os especialistas em assuntos devem, em seguida, delinear as prioridades entre aqueles itens. (HAZEN, 2001, p. 12)

Segundo o autor, coleções de valor histórico e cultural devem ter uma atenção diferenciada:

[...] a influência de coleções tradicionais, da mesma maneira pesa em decisões para o desenvolvimento de coleções e para preservação. Coleções historicamente importantes incorporam com freqüência um certo número de raridades, de forma que deve ser considerada a necessidade de preservação de suportes, bem como da informação. Como regra geral, essas áreas merecem esforços especiais para sua manutenção. (HAZEN, 2001, p. 12)

De acordo com mesma idéia de Hazen, Ogden (2001b) acredita que a preservação deve fazer parte da política de desenvolvimento de coleções. De acordo com a autora, essa política deve ser baseada nos estatutos institucionais, que mencionam os objetivos a serem atingidos.

A política de acervo ajuda a determinar as prioridades de conservação porque estabelece o nível em que a instituição desenvolve sua coleção, seja em que assunto for. Este nível, por sua vez, comumente determinado pela importância de uma dada coleção para projetos da instituição e, em última instância, para sua missão. (OGDEN, 2001b, p. 18) 
O bibliotecário de livros raros, por exemplo, não precisa ser um especialista em restauração, mas, de acordo com Cave (1976), precisa conhecer as causas de deterioração dos materiais, diagnosticar os danos sofridos pelo livro e até prescrever medidas de prevenção. Ele também participa da avaliação dos livros que serão escolhidos para uma possível restauração.

\subsection{Programa de preservação}

Valle (1991), em seu estudo, tenta esclarecer a necessidade e a importância de se adotar políticas de preservação e conservação em bibliotecas universitárias, mas deixa claro que tem consciência que a sensibilização de bibliotecários e gerentes de bibliotecas não é uma tarefa fácil. A autora enfatiza que quando se entende "que cada obra é um meio de comunicação através do tempo e que esta comunicação é essencial para o conhecimento do passado e o desenvolvimento do futuro” fica fácil entender a necessidade de preservação desses materiais.

Valle cita que a política de preservação e conservação deve incluir planejamento a longo e a curto prazo:

[...] a curto prazo, envolve a preservação de materiais bibliográficos que já trazem em si a semente de sua própria deterioração, como, por exemplo, o tratamento de materiais acidificados. A longo prazo, engloba medidas preventivas para materiais ainda não danificados, incluindo a aquisição de documentos em materiais livres de acidez. A preservação a longo prazo é cíclica, requer que as atividades sejam repetidas periodicamente. (p. 53)

O planejamento para preservação, de acordo com Ogden (2001a), exige avaliações do acervo como: em que medida o acervo se encontra em situação de risco, que partes do acervo têm maior valor permanente, a disponibilidade de recursos e a viabilidade política de certas ações. Esses resultados serão reunidos em uma lista de prioridades.

Para dar início ao processo de fixação das prioridades institucionais de preservação, são necessários dados confiáveis sobre as dimensões do problema de preservação. Devem ser colhidas informações sobre a extensão e os tipos de deterioração presentes, sobre as condições ambientais em que os materiais estão armazenados e utilizados e sobre os sistemas e as políticas, 
tais como deteç̧ão e supressão de incêndio e medidas de segurança que protegem as coleções contra danos, destruição ou perda. (p. 8)

Existem verdadeiros manuais de como se planejar um programa de preservação de acervos. Foi adotado neste trabalho o texto de Zuñiga, A importância de um programa de preservação em arquivos públicos e privados. Mesmo que esse tenha a intenção de privilegiar arquivos, o texto vem de uma adaptação de programas de preservação para bibliotecas. Então servirá como base teórica para esse levantamento.

Zuñiga (2002, p. 75) define programa de preservação como:

[...] um instrumento de planejamento capaz de operacionalizar objetivos e políticas, equacionando as necessidades de recursos humanos ou de equipamentos, levantando custos necessários, estabelecendo prioridades e organizando-se em um cronograma de trabalho, a curto, médio e longo prazo, capaz de atender a instituição como um todo.

Ela menciona que, para o programa ser realizado com sucesso, é necessário satisfazer alguns requisitos, tais como:

- Basear-se nos planos institucionais já existentes para definir os objetivos institucionais;

- Contar com o apoio de todos os escalões profissionais, do presidente aos voluntários;

- Trabalhar em grupo, pois é um método de trabalho muito eficaz, contando com a participação de membros de vários setores, o que favorece na tomada de decisão;

- Colocar tudo por escrito, não apenas os relatos de discussões, mas todo o trabalho realizado;

- Conhecer o acervo, o edifício e o entorno.

Zuñiga (2002, p. 77) sugere um modelo de organização do programa de preservação, que deve conter:

1. Ações preparatórias: reúnem documentos necessários ao planejamento como objetivo institucional, políticas institucionais e diretrizes institucionais;

2. Diagnóstico de preservação; 


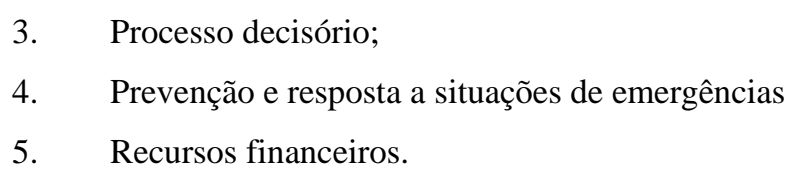

O diagnóstico de preservação é a etapa em que são planejados e realizados levantamentos capazes de apresentar a situação real do acervo e edifício de guarda. Segundo Zuñiga, nesse documento deve conter uma breve descrição bibliográfica, estado de conservação, danos visíveis, condições do material de acondicionamento, políticas existentes, frequência de uso, data e nome de quem fez o levantamento. Também é importante para essa etapa estabelecer qual a metodologia de trabalho a ser utilizada, se serão documentos item-a-item ou por amostragem aleatória.

No processo decisório é hora de convocar o grupo para avaliar os itens que terão prioridades, sem privilegiar ninguém. Nessa etapa é importante que todos participem e estejam envolvidos com a tomada de decisão. Segundo a autora, deve-se considerar, para estabelecer prioridades, os seguintes valores:

- Valor informacional;

- Valor histórico;

- Valor administrativo;

- Valor associativo: quando tem relação a algum indivíduo, lugar ou grupo;

- Valor evidencial: quando podem servir de prova legal ou histórica;

- Valor monetário.

A prevenção e resposta a situações de emergência é a etapa onde se estabelece os procedimentos e medidas em casos de sinistros e desastres. Zuñiga divide em medidas preliminares, medidas preventivas e medidas de respostas, essa última quando já ocorreu a emergência ou o desastre.

Dependendo do estado do acervo, das medidas a serem adotadas, consultores externos são contratados e deverá existir um orçamento para cada caso. A autora alerta que “o orçamento institucional será insuficiente para cobrir todos os gastos necessários” podendo ser preciso solicitar apoio a “instâncias governamentais, agências de fomento, organismos internacionais, bancos, comércio, indústria, o que é feito através da elaboração de projetos.” 


\subsection{Programa de prevenção de emergências}

Fazem parte de programas de preservação de acervos, principalmente de acervos valiosos, como é o caso de coleções de livros raros, programas de prevenção contra desastres ou sinistros. De acordo com Ogden (2001c), "um número cada vez maior de profissionais sabe que as pequenas emergências podem ser contidas quando os membros da equipe estão preparados para agir com rapidez”.

O planejamento para os casos de emergências é complexo; o plano escrito é o resultado final de uma ampla faixa de atividades preliminares. O processo como um todo se tornará mais eficiente se for atribuído formalmente a uma única pessoa, que será o planejador da instituição para casos de emergência, assistido talvez por uma equipe ou comissão de planejamento. O diretor da instituição pode desempenhar este papel primário ou delegar sua responsabilidade, mas é importante lembrar que o processo só será eficaz se for apoiado pelo primeiro escalão da organização. O planejador estabelecerá um cronograma para o projeto e definirá o alcance e as metas do plano, o que dependerá, em grande parte, dos riscos enfrentados pela instituição. (OGDEN, 2001c, p. 7)

Como foi visto, um plano de emergência envolve todos os que têm contato com a coleção, mas exige que exista uma pessoa que seja a responsável por elaborar os procedimentos e metas. É sabido que para qualquer tipo de acervo existem alguns riscos que podem ser prevenidos; segundo Ogden (2001c), um levantamento dos riscos, uma pesquisa de acontecimentos passados e problemas anteriores ajudam na identificação dos perigos.

Na etapa de identificação de riscos, a autora lista várias perguntas sobre riscos geográficos, climáticos e de outra natureza que possam ameaçar o prédio e seu acervo e devem ser respondidas nessa etapa:

- Existe suscetibilidade da instituição a furacões, tornados, inundações repentinas, terremotos ou incêndios florestais?

- Existe a possibilidade de racionamento de eletricidade, disparo de sistemas de sprinkler, falhas no suprimento de combustível ou água, vazamentos químicos, incêndios premeditados, ameaças de bomba? 
- Existem, nas proximidades da instituição, indústrias químicas, rotas de transporte de materiais perigosos ou projetos de construções?

- Em relação ao edifício na qual está armazenada a coleção, está situado em um declive e seu subsolo fica acima do nível de inundação?

- As calhas e os drenos estão funcionando bem? São limpos com regularidade? As janelas e clarabóias estão bem vedadas? O prédio tem antecedentes de infiltrações ou outros problemas estruturais?

- Os extintores de incêndio são em número suficiente e inspecionados regularmente?

- O prédio dispõe de alarmes contra incêndio e de um sistema de extinção de incêndio?

- As saídas de incêndio estão desbloqueadas?

- Qual a idade da fiação elétrica?

- Os aparelhos elétricos são desligados das tomadas à noite?

- Existem detectores de água?

- Ocorrem problemas com o sistema de controle de clima?

É interessante notar que em um planejamento de emergências deve constar todo tipo de informação que venha beneficiar a preservação do acervo. Ainda seguindo a lista de Ogden (2001c), é importante que no levantamento de riscos conste a vulnerabilidade dos objetos que compõem o acervo como, por exemplo, conhecer os tipos de materiais armazenados, como e onde o acervo está armazenado, se as estantes estão presas a elementos estruturais do prédio e se são estáveis. Analisar os procedimentos de segurança, limpeza e conservação, perigos de roubo, vandalismo e infestação de insetos são pontos que não podem faltar em levantamento de riscos.

Respondidas todas essas perguntas, de acordo Ogden (2001c, p. 9), “o planejador para casos de emergência deverá elaborar um programa com metas concretas, recursos disponíveis e um cronograma de atividades voltadas para a eliminação do maior número possível de riscos.”

Segundo a autora, no caso de acervos de valor permanente, como livros raros, os cuidados devem ser redobrados; instituições detentoras desses materiais precisam adotar bons sistemas de proteção contra incêndio e inundações e possuir sistemas de detecção entregues a operadores profissionais 24 horas por dia. Outra ação para reduzir a 
vulnerabilidade do prédio e do acervo, de acordo com Ogden (2001c), é o inventário do acervo; isso ajudará na identificação de obras caso aconteça algum desastre ou roubo.

Não pode faltar em um plano de emergência o estabelecimento de prioridades. Segundo Ogden (2001c, p. 12), “a primeira prioridade em qualquer emergência é a segurança humana. O salvamento de peças culturais jamais deverá colocar em risco a vida de funcionários e usuários”. Deve ser feita com antecedência uma identificação e registro das obras do acervo que, em caso de acidente, terão prioridade no salvamento. A manutenção e a atualização do plano são fundamentais para o melhor funcionamento quando as metas forem solicitadas.

\subsection{Segurança contra roubos em acervos raros}

Em uma coleção de livros raros, onde o roubo de itens valiosos é uma possibilidade cotidiana, a segurança deve ser uma das grandes preocupações da biblioteca e da sociedade, pois se trata de acervos, muitas vezes, de alto valor histórico, cultural e artístico do país, e cabe aos gerentes dessas coleções garantirem a permanência desses itens nas instituições de guarda. Um plano de segurança contra roubos não pode faltar em um Programa de Preservação.

Tomou-se como base para esse tópico o folheto Segurança em acervos raros, do extinto Grupo de Estudo em Obras Raras do Rio de Janeiro-GEORJ, publicação que teve como coordenadora Valeria Gauz, ex-coordenadora da Divisão de Obras Raras da Biblioteca Nacional do Rio de Janeiro. Segundo Gauz (1994, p. 13), administrar uma coleção de acervos raros é difícil, pois essa sofre "constantes riscos de furto, dado o alto valor de mercado atribuído ao livro raro. Também os livreiros passaram a ter problemas diante da possibilidade de comprar e vender um livro roubado".

Gerentes e bibliotecários devem estar atentos a todo tipo de pessoa; não só os bibliomaníacos roubam livros; alguns, de acordo com a autora, "legítimos pesquisadores e pessoas de renome podem, também, ser ladrões. Existem fortes evidências e exemplos concretos de que muitos dos grandes roubos tenham envolvido pessoas da própria instituição”.

É importante fazer uma identificação cuidadosa dos antecedentes de novos empregados. Bom ambiente de trabalho e consciência do que representa a coleção, são, provavelmente, a melhor segurança contra roubos internos - 
que, infelizmente, acontecem mais que o desejado -, não se descuidando de uma eficiente supervisão. (GAUZ, 1994, p. 13)

Vários são os procedimentos que devem ser adotados por uma instituição para a prevenção de roubos. É importante que esteja tudo documentado e que funcionários e usuários sejam informados das regras a serem adotadas. Devem ser tratados de igual maneira, sem distinção entre as pessoas que trabalham com o acervo e as que irão consultar o acervo.

Segundo a autora, um funcionário ou comitê deve ser responsável pela segurança do acervo. O pessoal interno deve receber formação adequada para estar alerta quanto a ameaças de roubo e também quanto a instruções sobre os procedimentos oficiais, como responsabilidades e direitos legais ao lidar com esse tipo de problema.

Funcionários devem seguir as mesmas normas que os usuários no que diz respeito a manuseio de livros, colocando, inclusive, na estante, um registro (que pode ser um rascunho de ficha catalográfica) ao retirar o livro para preparo técnico. Da mesma forma, a revista de bolsas e sacolas de funcionários e usuários deve ser feita à saída por um segurança. (GAUZ, 1994, p. 14)

Gauz (1994, p.14) faz um alerta para os pontos de acesso do prédio e sala de guarda da coleção. Segundo a autora,

[...] o prédio ou seção que abriga uma coleção especial deve ter poucos pontos de acesso, sendo a mesma a porta de entrada e saída, tanto para funcionários quanto para usuários. A área do público deve ser reservada, não tendo, este, acesso à área interna de funcionários nem às estantes. [...] Deve haver um controle eficaz no uso de chaves e, ao fechar a biblioteca, ou o prédio, este sofrer cuidadosa vistoria a fim de assegurar que nenhuma pessoa não autorizada se encontra no local.

Existe também uma atividade que não é só usada em bibliotecas de coleções valiosas, mas é um procedimento que faz parte da rotina de processo técnico de qualquer biblioteca. Após o registro do número de tombamento no exemplar, é à hora da marca de propriedade; em acervos de uso corrente ainda é muito utilizado o carimbo 
da instituição no exemplar. Mas, em se tratando se livros raros, não é recomendado uso de carimbo direto no papel.

Sobre esse assunto, Gauz (1994) destaca alguns métodos de marcação de papel utilizados em acervos de uso corrente; não são recomendados para livros raros, por exemplo, gravação em relevo; segundo ela, essa marcação agride as fibras do papel, com o tempo, fazendo-as se romper; perfuração também não é recomendada, pois desfigura o documento e agiliza o processo de destruição da folha.

No caso de livros raros ainda se utiliza bastante o carimbo e o ex libris. O carimbo, segundo a autora, é um método utilizado desde a Antiguidade e "os componentes das tintas devem ser observados em suas qualidades e propriedades, podendo ser identificáveis como estáveis e instáveis, do ponto de vista da conservação”. Deve-se optar pela cor preta e por materiais inorgânicos, pois não causam danos ao papel e são mais duráveis.

Existe também a opção por uma catalogação descritiva que faça uma análise bibliológica do livro. Destacar cada detalhe do exemplar tornando-o único é um método eficiente de registro dos exemplares que compõem o acervo. Segundo Gauz (1994, p.23),

[...] as marcas de propriedade podem ser habilmente apagadas do livro, sem deixar vestígios. Já a informação, em uma ficha catalográfica, que um determinado exemplar sofreu ação de inseto, tem anotações em tais páginas, selos ou carimbos em determinados locais, pode levar a uma identificação do livro, mesmo que este tenha sofrido adulterações.

Cabe à instituição detentora de um acervo valioso escolher qual a melhor método de marcação de propriedade para o seu caso, sem se esquecer de priorizar a integridade física da obra. 


\section{Capítulo IV}

\section{Apresentação metodológica}

\section{Problema}

Quais são as práticas de organização e preservação de acervos de livros raros adotadas pela Biblioteca Nacional do Rio de Janeiro?

\section{Objetivo}

Identificar e descrever as práticas de organização e preservação de acervos de livros raros adotadas pela Biblioteca Nacional do Rio de Janeiro.

\section{Objetivos Específicos}

$>$ Identificar as práticas adotadas pela instituição pesquisada em relação ao Programa de Formação e Desenvolvimento do acervo;

> Identificar as práticas adotadas pela instituição em relação ao Programa de Preservação do acervo;

> Destacar a importância de se preservar o original impresso do livro raro como forma de preservação do patrimônio histórico e cultural brasileiro.

\section{Justificativa}

A literatura sobre o assunto ressalta que a maioria das instituições brasileiras ainda está delimitando as diretrizes de formação e desenvolvimento do acervo e colocando em prática os procedimentos de uma política de preservação. Diante desse quadro, é interessante verificar quais são práticas escolhidas pela Biblioteca Nacional do Rio de Janeiro, pois se trata de uma das instituições brasileiras com mais experiência no que diz respeito à organização e à preservação do acervo de livros raros, servindo como referência para as demais instituições. A escolha pela Biblioteca Nacional justifica-se 
pela experiência tanto na organização como na preservação de livros raros. A sua história comprova que se trata de um dos acervos mais valiosos de posse de uma instituição pública. Esse acervo descendente de uma Biblioteca de Reis que na época se tinha a ideia, de que essas bibliotecas deveriam guardar todos os saberes acumulados e todos os livros escritos do mundo. Essas bibliotecas representavam a cultura de uma nação.

\section{Metodologia}

A pesquisa tem um caráter descritivo, sendo um estudo de caso da Biblioteca Nacional do Rio de Janeiro. Foi feito um levantamento bibliográfico sobre o tema; levantamento histórico da instituição pesquisada; visita ao prédio sede, ocasião em que foram feitas entrevistas com funcionários da Coordenadoria de Preservação e da Divisão de Obras Raras. Fez-se uso também de Relatórios de gestão da instituição, que estão disponíveis, no site da Fundação Biblioteca Nacional. Foi analisado o conteúdo das informações obtidas durante as entrevistas a fim de se efetuar uma correlação com o referencial teórico pesquisado. 


\section{Capítulo V}

\section{Breve Histórico da Biblioteca Nacional}

A história da Biblioteca Nacional não é diferente das grandes bibliotecas nacionais espalhadas pelo mundo, sendo estas na maioria herança de uma biblioteca de reis. Segundo Schwarcz (2003, p.13) a biblioteca de D. João I, conhecido como “O Boa Memória” que reinou de 1385 a 1433, já possuía uma respeitável biblioteca ou livraria, como se chamava na época. Seus sucessores como D. Duarte (1433 a 1438), D. Afonso V (1438 a 1481), D. João V (1706 a 1750) se dedicaram a formação e desenvolvimento da Real Biblioteca, que na época era muito famosa e considerada uma das mais completas do Velho Mundo.

Pinheiro (2001, p. 244) divide a cronologia da Biblioteca Nacional em cinco marcos:

- Primeiro marco:

D. João V desencadeou um surpreendente processo de enriquecimento da Real Biblioteca. Reuniu os volumes da Livraria da Sereníssima Casa de Bragança à Biblioteca e com a ajuda de diversos bibliotecários e eruditos multiplicaram o acervo para 60 mil volumes.

- Segundo marco:

Em $1^{\circ}$ de novembro de 1755, acontece um terremoto devastador em Lisboa, cidade sede da Real Biblioteca, que destruiu o acervo. Por ocasião desse acontecimento, D. José organizou por compra e doações outra biblioteca com o nome de Ajuda. Esta recebeu grandes coleções como a de Diogo Barbosa Machado, um grande bibliófilo português.

- Terceiro marco:

A vinda da corte portuguesa para o Brasil em 29 de novembro de 1807, trazendo toda a estrutura administrativa do Reino. Eram cerca de 15.000 pessoas que vieram com todos os seus bens, inclusive suas bibliotecas particulares. Também veio para o Brasil a Família Real e suas duas bibliotecas, uma era da Rainha D. Maria I, identificados pelo carimbo com a coroa real e com a legenda "Da Real Bibliotheca”. Os livros da Casa do Infantado que pertencia ao príncipe regente D. João, identificados pelo carimbo com a 
coroa de infante, foram transportados para o Rio de Janeiro depois da chegada da corte ao Brasil.

- Quarto marco:

Segundo Pinheiro, o quarto marco é o dia 29 de outubro de 1810, data escolhida como a da sua fundação. Nessa data o príncipe regente amplia o espaço de depósito dos livros para o andar térreo da Casa da Ordem Terceira do Carmo. Em 1811 a Real Biblioteca foi aberta a estudiosos, com a licença régia prévia. E em 1814, foi aberta a todo o público.

- Quinto marco:

E finalmente o quinto marco é o dia 29 de agosto de 1825, data da assinatura da Convenção Adicional ao Tratado de Paz e Aliança entre o Brasil e Portugal. O Brasil pagou a Portugal dois milhões de libras esterlinas pela Biblioteca.

Segundo o site da Fundação Biblioteca Nacional, administrativamente a Biblioteca Nacional esteve subordinada ao antigo Ministério do Interior e Justiça, depois ao Ministério da Educação e Saúde. Com a criação do Ministério da Saúde, ela passou integrar o Ministério da Educação e Cultura. Em 1981, o órgão passou à administração indireta, fazendo parte da Fundação Nacional Pró-Memória, até o ano de 1984, quando, junto com o Instituto Nacional do Livro, passou a constituir a Fundação Nacional Pró-Leitura.

Em 1990, a Biblioteca Nacional, com sua biblioteca subordinada, a Euclides da Cunha, do Rio de Janeiro, e o Instituto Nacional do Livro, com sua Biblioteca Demonstrativa, de Brasília, passaram a constituir a Fundação Biblioteca Nacional (FBN). A partir de 2004, através do seu atual estatuto, Decreto n. 5.038 de 7 de abril de 2004, é composta por um Presidente, nomeado pelo presidente da República, um diretor executivo, e seis Diretores à frente de dois centros: Centro de Processos Técnicos e Centro de Referência e Difusão; e, quatro Coordenadorias-gerais: de Planejamento e Administração; Pesquisa e Editoração; Livro e Leitura; e, Sistema Nacional de Bibliotecas Públicas.

Sob o novo estatuto de Fundação, a Biblioteca Nacional ampliou seu campo de atuação, passando a coordenar as estratégias fundamentais para o entrelaçamento de três dos mais importantes alicerces da cultura brasileira: biblioteca, livro e leitura. Assim a instituição coordena o Sistema Nacional de Bibliotecas Públicas e a política de incentivo à leitura através do Proler. 
Para garantir a manutenção de seu acervo, a FBN possui laboratórios de restauração e conservação de papel, estando apta a restaurar, dentro das mais modernas técnicas, qualquer peça do acervo que precisar desse serviço. Possui também oficina de encadernação e centro de microfilmagem, fotografia e digitalização.

O acervo da Biblioteca Nacional está organizado de acordo com a tipologia documental e está dividido em sete coleções: Obras gerais, Referência, Iconografia, Música, Periódicos, Obras Raras, Manuscritos e Cartografia. Existe o projeto de construção do prédio anexo onde será instalada a futura Hemeroteca Nacional, o que resolverá um dos maiores problemas da Biblioteca: a falta de espaço. 


\section{Capítulo VI}

\section{Estudo de Caso}

\subsection{Organização de livros raros na Biblioteca Nacional}

A Divisão de Obras Raras (DIORA) da Biblioteca Nacional foi criada em 24 de janeiro de 1946 com o nome de "Seção de livros raros”. De acordo com a atual chefe da Divisão, Ana Virginia Pinheiro, uma das maiores especialistas em livros raros do Brasil, no final dos anos 1980, a seção passa ser chamada “Seção de obras raras” e, já no final da década, de “Divisão de obras raras”. Na opinião de Ana Virginia,

Essa mudança foi catastrófica. Quem pensou nisso não tinha muita noção do que era a ciência da Biblioteconomia, pois quando você pensa em obra rara, você pensa em material de qualquer natureza e não se restringe à tipologia documental. Então, qualquer um poderia entender que um material, sendo considerado raro, estaria aqui. Mesmo que seja um manuscrito, material cartográfico, iconografia, sendo uma obra rara, estaria aqui. Mas não é assim que funciona. Embora ela tenha sido chamada nos anos oitenta de "Seção de Obras Raras", ela foi toda estruturada sob o ponto de vista de distribuição e aquisição de mobiliário como uma área para a guarda de livros, de material bibliográfico. Então ela é efetivamente uma seção, uma divisão de livros raros, e não uma divisão de obras raras. [informação verbal, 30/9/2009]

O acervo da Divisão de obras raras é formado em grande parte por livros que pertenceram à Real Biblioteca. Há uma variedade de áreas do conhecimento, como títulos religiosos, fábulas, livros de viajantes, Direito, Medicina, ciências, boas maneiras, culinária, gramática, literatura, Biologia, Matemática, incunábulos, Bíblias, incunábulos brasileiros, livros impressos pela Imprensa Régia, primeiras edições de obras célebres ou autores consagrados. Um dos maiores tesouros da coleção de livros raros da Biblioteca Nacional é a Bíblia de Mogúncia.

Segundo Ana Virgínia, nos anos 1980 foi formalizada uma instrução de serviços que estabelecia o que deveria ir para a Divisão de Obras Raras. Esta é a única Divisão da Biblioteca Nacional que possui um documento que formaliza critérios de formação e 
desenvolvimento da coleção. Essa instrução foi baseada a partir de pesquisa e reunião de várias comissões, que decidiram os critérios de raridade para Biblioteca Nacional.

O documento Critérios de raridade adotados pela Fundação Biblioteca Nacional enfatiza que o primeiro e principal critério de raridade bibliográfica para uma biblioteca deve ser baseado na política da instituição e os seus objetivos. E destaca que "uma obra pode ser rara em sua biblioteca, e para a Biblioteca Nacional não, devido à importância do contexto da formação dos objetivos de cada instituição”. Seguindo a mesma linha, Ana Virginia fala sobre o critério de raridade para Biblioteca Nacional:

\footnotetext{
Esses critérios não servem para nenhuma outra instituição. [...] Os critérios da Biblioteca Nacional só se prestam para a Biblioteca Nacional porque o leitmotiv, a razão que levou à formalização dos critérios, foi a exiguidade de espaço para armazenamento e, principalmente, das condições ideais de armazenamento, isto é, se a Biblioteca Nacional é uma instituição de memória, todo e qualquer espaço na Biblioteca Nacional é uma área de salvaguarda da memória. A área de livros raros vai ser uma área de acesso mais restrito, de salvaguarda mais restrita. Então ficará na Divisão de obras raras o que há de mais raro entre os raros, o que não quer dizer que entre Obras Gerais não haja livros, manuscritos e iconografias raras. Existem livros raros na Biblioteca toda. Existem livros nas Obras Gerais que o leitor vem e consulta que em outra biblioteca ele precisará preencher termo por escrito, pois aqui está em obras gerais e, em outras instituições, fica em áreas mais reservadas. [informação verbal, 30/9/2009]
}

Os critérios de raridade da Biblioteca Nacional estão baseados em uma data limite: 1720. Todos os livros do acervo que tenham a data de publicação até 1720 estão armazenados na Divisão de Obras Raras. Ana Virginia explica o porquê dessa data:

Os critérios de raridade da Biblioteca Nacional são os livros publicados até o ano de 1720, ou seja, 1720 é um referencial que a Biblioteca Nacional usou para abranger todo o século $X V$, todo o século XVI e todo o século XVII. Porque a Antiguidade é considerada mérito, pois são obras publicadas artesanalmente, isto é, manufaturadas. O século XVIII considerado o boom editorial, onde todo o mundo publicava de tudo e onde surgiram várias máquinas, máquinas de impressão, que imprimiam frente e verso. No século XVIII já não é mais assim, embora o livro ainda seja editado artesanalmente, porém existe uma tradição na história do livro, que os primeiros vinte anos de um século, num livro, guardam ainda as características do século 
anterior, por esse motivo a data 1720. É um critério... A Biblioteca poderia dizer que é 1750, ou 1780. Em princípio, pelo padrão internacional, é considerada edição artesanal tudo o que é publicado até o ano de 1800 inclusive. 1801 já não é mais, porque o século XIX é o século da edição em papel de polpa de madeira. É claro que um livro publicado até 1820 traz as características do século anterior. Toda biblioteca também considera isso, mas o nosso critério são os séculos XV, XVI, XVII e o XVIII, até 1720. Século XIX Brasil, edições de luxo e edições artesanais: tudo isso sob o critério do olhar crítico de um bibliotecário que tenha conhecimento da história do livro. [Ana Virginia, informação verbal, 30/9/2009]

Vale ressaltar que não são somente livros publicados até a data 1720 que estão armazenados na Divisão, fazem parte dos critérios de raridade da Biblioteca Nacional:

- Primeiras impressões (século XV-XVI);

- Impressões dos séculos XVII e XVIII;

- Brasil -século XIX;

- Edições clandestinas;

- Edições de tiragem reduzida;

- Edições especiais (de luxo para bibliófilos)

- Exemplares de coleções especiais (regra geral com belas encadernações e $E x$ libris);

- Exemplares com anotações manuscritas de importância (incluindo dedicatórias);

- Obras esgotadas;

A DIORA tem como um de seus projetos em andamento a Formação e Desenvolvimento de Coleções em Obras Raras. O objetivo central é disponibilizar, mediante avaliação, um acervo composto por coleções de obras raras, segundo critérios de armazenamento, disseminação e acesso adequados à tipologia documental (livro raro), à natureza dos materiais (papéis de trapos e de polpa de madeira, pergaminhos, couros, tecidos) e à "qualidade arquivística” dos itens (impressos bibliográficos dos séculos XV a XVIII, “incunábulos” brasileiros e raridades incontestes dos séculos XIX, XX e XXI). A justificativa desse projeto diz respeito à tipologia documental do material que hoje se encontra armazenado na Divisão, por exemplo, periódicos raros ocupam 209,33 metros lineares de prateleiras; existem também impressos avulsos, recortes de 
jornais, fotografias, cromos, microfilmes de itens do acervo bibliográfico e hemerográfico.

Esse projeto busca resgatar os acervos que, de acordo com os critérios de raridade da Biblioteca Nacional, deveriam estar armazenados na Divisão e não estão, atualmente, por falta de espaço. O remanejamento desses materiais para suas Divisões de direito e a transferência de livros raros que estão alojados na Divisão de Obras Gerais garantirão, futuramente, a preservação e o controle do patrimônio de raridades salvaguardadas na Biblioteca.

Na opinião de Ana Virginia, a implantação de uma política de formação e desenvolvimento de coleções facilitará o acesso de obras aos usuários. Muitos materiais, por estarem na Divisão de Obras Raras, mas não considerados raras, têm um acesso mais restrito; por exemplo, a Divisão fecha às 16h para o público, sendo que a área de atendimento da Biblioteca vai até as 20h.

Outro projeto implantado na Divisão é a consolidação das bases catalográficas. Ana Virginia comenta sobre a origem desse projeto:

\footnotetext{
Durante anos, a Biblioteca teve vários patrocínios para vários projetos e, curiosamente, cada um desses projetos foi delineado como se o projeto anterior nunca tivesse acontecido, então temos casos de obras que foram catalogadas duas vezes em outros projetos. Assim, o nosso trabalho é fazer toda uma consolidação das bases e de uniformizar essas catalogações, ou seja, de escolher uma catalogação e centralizar nessas catalogações todas as notas que existem nas outras [bases] e então padronizar essas notas. [Ana Virgínia, informação verbal, 30/9/2009]
}

A catalogação de livros raros feita na Biblioteca Nacional utiliza como padrão de descrição bibliográfica o ISBD (A). Durante alguns anos, a Biblioteca fez uso do manual de catalogação da Library of Congress, o DCRB, mas, por esse, motivo não pôde cooperar com o catálogo da Associação de Bibliotecas Nacionais da IberoAmérica (ABINIA), que elegeu o ISBD(A) como código de catalogação. Segundo o site do PLANOR, essa Associação foi fundada no México em 1989. A ABINIA é o resultado da associação de governos ibero-americanos para o desenvolvimento das Bibliotecas Nacionais da ibero-américa. Dentre seus objetivos específicos está a elaboração de um catálogo coletivo de monografias dos séculos XVI a XIX depositadas nos acervos das bibliotecas nacionais ibero-americanas. A Biblioteca Nacional, através 
do PLANOR, é co-participante no projeto do catálogo NOVUM REGESTRUM e tem trabalhado para disponibilizar as descrições bibliográficas dos exemplares - de obras entre 1501 e 1900, pertencentes ao seu acervo e ao acervo das instituições culturais brasileiras cadastradas no PLANOR.

O projeto de Consolidação das Bases de Obras Raras implantado em 2005 visa a consolidar os catálogos existentes na Divisão de Obras Raras para tornar relevante e eficaz o processo de busca e recuperação da informação. Foram consolidados os catálogos em fichas, de autores, títulos e assuntos, em um catálogo dicionário, favorecendo a pesquisa e poupando o tempo do leitor.

Existem duas bibliotecárias na Divisão disponíveis para a atualização e migração do arquivo de transferência para a Base da Biblioteca Nacional. O arquivo de transferência é feito na Base MicroIsis. É uma base interna cujo acesso só é permitido dentro da Divisão de Obras Raras. Segundo a bibliotecária Ana Paula, o trabalho de catalogação feito na Divisão é composto pela análise bibliológica, trabalho feito exclusivamente por estagiários de Biblioteconomia, e pela atualização das notas baseada num roteiro que estabelece a ordem das notas criadas por Ana Virginia.

De acordo com Ana Paula, as catalogações já estão prontas; o que é feito é uma atualização com acréscimo de notas, as quais são geradas na análise bibliológica. A primeira nota é a descrição didascálica, que consiste na transcrição literal da folha de rosto; usa-se duas barras (//) como indicativo de mudança de linha. A segunda nota são as assinaturas, a paginação, notas em corandel; em seguida são as notas locais, que são aspectos inseridos no livro depois da sua publicação, como encadernação, Ex libris, Ex dono, sendo o último aspecto a ser registrado nas notas o carimbo, no caso se possui carimbo da Real Biblioteca.

Já a análise bibliológica, segundo Rodrigues et al (2006), “permite arrolar todas as informações intrínsecas e extrínsecas, originais ou acrescentadas ao livro raro, segundo terminologia específica e consagrada”. O estagiário André, que faz análise bibliológica dos livros junto com outros dois estagiários, explica como é feita, na prática, esse tipo de análise:

Cada vez que um livro vai sair daqui [Divisão de Obras Raras] para fazer uma exposição, ou um trabalho de restauração, para a digitalização, antes é feita uma análise bibliológica. [...] Esse tipo de análise é muito criteriosa, minuciosa, descreve cada detalhe do livro, tipo de encadernação, se a encadernação é original, ou se é recente, tipo de material em que foi feita a 
encadernação, se é de couro ou pergaminho, o tipo de papel, marcas de impressão; se for a marca de um impressor famoso, a gente tem que colocar; tipo de caracteres, como romano - às vezes são caracteres gregos -, os que estão em itálico a gente chama de aldino, por causa de Aldo Manucio. Na folha de rosto, anotam-se detalhes; fazemos uma descrição detalhada do título que está na página de rosto porque, na verdade, muitas obras antigas não tinham página de rosto. O texto começa da primeira folha, com a palavra Incipit, "aqui começa"; nesse caso é preciso fazer uma transcrição de algumas linhas como forma de identificação do texto. É feito uma pesquisa bibliográfica para identificar aquela obra. Seguimos bibliográficas de autores consagrados e manuais feitos pela Ana Virginia. [...] A análise bibliológica é um trabalho exclusivo de estagiários, com a supervisão de bibliotecários. [estagiário André, informação verbal, 30/9/2009]

Segundo André, quando se vai iniciar uma análise bibliológica, o primeiro passo é fazer uma pesquisa no catálogo da Biblioteca Nacional. É importante verificar se existem outros exemplares da mesma edição do livro, pois, caso exista, ele terá que fazer uma análise para cada um dos exemplares, independentemente se estes estão na Divisão de Obras Gerais.

O mesmo exemplar é aquele que foi impresso na mesma data, pelo mesmo impressor, na mesma época. Não sei qual foi o motivo de o livro ser considerado raro, pode até já existir uma nota de explicação porque esse exemplar encontra-se nas obras raras e os outros na obras gerais. Nesse caso é importante buscar essa informação. Faz-se uma pesquisa bibliográfica do livro para descobrir essa informação. [Estagiário André, informação verbal, 30/9/2009]

A Biblioteca Nacional é pioneira na divulgação dessas particularidades do livro raro no catálogo on line. Segundo a bibliotecária Ana Paula, desde quando Ana Virginia assumiu o cargo de chefia, em 2004, ela veio com uma proposta de fazer uma catalogação mais completa e fazer a análise bibliológica das obras. Nem a Library of Congress ou qualquer outra base européia disponibilizou esse tipo de informação. Segundo Ana Paula, somente na Espanha informações sobre as assinaturas e notas em corandel são disponibilizadas; mas com o nível de detalhes da Biblioteca Nacional do Rio de Janeiro ainda não existe. (ver ANEXO A) 
A DIORA tem em seus armazéns 1730,09 metros lineares de livros impressos de todos os tempos. A forma de organização de livros nas estantes é através do sistema de localização fixa, utilizado em todo o prédio sede da Biblioteca Nacional. É considerado o sistema de ordem do livro na estante mais adequado para acervos de memória, pois leva em consideração as características do livro.

A Divisão de Obras Raras possui um Serviço de Referência e Atendimento ao usuário e está sob a responsabilidade do bibliotecário Luís Antônio. Os serviços oferecidos são: pesquisa, cadastro de leitores, permissões para reprodução documental (microfilme, fotografia convencional e fotografia digital, filmagem) e acesso ao banco de imagens.

De acordo com a Norma para reprodução do acervo, disponível no site da Fundação Biblioteca Nacional, a reprodução do acervo é permitida somente para fins de pesquisa, de acordo com as normas institucionais. Em caso de pesquisa comprovada, poderá ser requisitada cópia em microfilme ou eletrostática, através de requisição e pagamento antecipados. Fotocópias não são permitidas. Todas as obras serão previamente avaliadas quanto ao estado geral de conservação física para fins de autorização de consulta ou reprodução de qualquer natureza.

No caso de microfilmagem de livros raros, primeiro o bibliotecário responsável faz uma identificação do livro no catálogo interno, identifica quantos exemplares existem na Biblioteca Nacional e avalia o estado físico da obra. Segundo Luís Antônio, é mais interessante para a Biblioteca Nacional possuir o microfilme do livro, pois é um suporte mais seguro em termos de preservação, do que a digitalização. Quando um usuário faz pedido da digitalização de um livro ou partes dele, o bibliotecário expõe esse interesse da Biblioteca pelo microfilme; então o usuário paga pelo microfilme e ganha uma cópia digitalizada da obra completa em CD. O microfilme fica com a Biblioteca.

Caso o título desejado esteja microfilmado, será permitida a consulta em máquinas leitoras de microfilme ou a reprodução do próprio microfilme. Todos os serviços reprográficos são cobrados de acordo com as tabelas de preços vigentes. No caso de reprodução por fotografia, é norma da Biblioteca que o pedido seja mediante o preenchimento de formulário próprio, com uma antecedência de 24 horas.

A Divisão de Obras Raras possui um Banco de Imagens digitalizadas de partes de livros de uso exclusivo da Divisão, formado a partir da devolução obrigatória de cópia de imagens fotografadas por usuários (ver ANEXO B). Existe uma bibliotecária 
responsável pela organização do Banco de Imagens, que explica como funciona o acesso do usuário a essas imagens:

\footnotetext{
O usuário que deseja a imagem de uma folha de rosto que existe no Banco de Imagens faz o pedido. Essa solicitação vai ser analisada; se for aceita, ele pode vir ao computador e, com um pen drive, copiar e colar a imagem. Ele não vai fotografar o livro, se existe a imagem no Banco. Mas ele tem que pagar $R \$ 2,00$ por imagem se o livro já estiver microfilmado. Se não estiver microfilmado, ele paga $R \$ 20,00$. Existem alguns acordos para fotografar; por exemplo, estudantes têm o direito de até quinze imagens sem cobrança e quinze páginas mediante apresentação de identidade da Universidade. [Bibliotecária Cristina, informação verbal, 01/10/2009]
}

Para consultas remotas, a Biblioteca Nacional dispõe de serviço de atendimento a distância, coordenado pela Divisão de Informação Documental (DINF). O serviço é destinado aos usuários não residentes no município do Rio de Janeiro e do Grande Rio. São oferecidos serviços de informação sobre o acervo, tais como: levantamento e compilação de registros bibliográficos; reprodução do acervo (microfilmagem e digitalização), obtenção de cópias de textos de periódicos através do Programa COMUT; pronta resposta (via correio eletrônico ou telefone). A DIORA, juntamente com a DINF, responde a pedidos de imagens a distância.

Quanto ao acesso das obras que estão na Divisão de Obras Raras, a Biblioteca Nacional não faz muitas restrições. Os funcionários não mostram livros a curiosos. Para consultar um livro que está em um dos três cofres da Divisão, o usuário irá preencher um formulário explicitando seus motivos. O pesquisador que quer consultar uma obra que está no cofre, primeiro irá consultar o microfilme. Segundo o bibliotecário Luís Antônio, se uma obra estiver disponível na íntegra na Biblioteca Digital da Fundação Biblioteca Nacional, o pesquisador não terá acesso ao livro impresso. São poucos os livros que estão microfilmados ou digitalizados; então, o pesquisador ainda tem o privilégio, na maioria das vezes, de manusear o livro. O cofre tem hora marcada para ser aberto e não é qualquer pessoa que tem acesso às obras lá guardadas. A especialista Ana Virgínia tem consciência da importância do contato do pesquisador com a obra:

Quando eu vim pra cá, em 2004, praticamente nós implantamos o Sistema de microfilmagem na íntegra. O leitor pedia a microfilmagem de um capítulo e a Biblioteca Nacional fazia isso. Era preparado, envolvia um custo 
impressionante e não fazia memória para a Biblioteca Nacional, porque levava um pedaço do livro. Então, de 2004 pra cá, eu acabei com isso que era xerox de luxo. Então todo esse trabalho de preparo era feito uma vez só porque aquele livro passou a ser consultado em microfilme. Então o livro tem materialidade, o livro tem uma estrutura material. Assim, não é possível um pesquisador consultar um livro raro só no microfilme. O microfilme ou a imagem digital não substituem o original em circunstância alguma, substitui apenas sob o ponto de vista de conhecimento do conteúdo. [...] Então o pesquisador tem acesso ao original que está microfilmado ou digitalizado na parte final dessa pesquisa. Normalmente ele tem algumas horas com o livro, o privilégio de uma ou duas horas sentadinho com o livro em sua posse ali, depois de haver esgotado toda a sua pesquisa no microfilme. Porém, quando o livro não está microfilmado, ele tem acesso ao original. A leitura é vigiada. Nós não temos ninguém no balcão, mas temos todo um sistema de câmeras estruturadas aqui, e a observação em sala de leitura pelas pessoas. [Ana Virginia, informação verbal, 30/9/2009]

Só é permitida a consulta local todo o acervo da Biblioteca Nacional mediante o preenchimento de formulário (ver ANEXO C), mas, como se trata de uma Biblioteca de Memória e que muitas vezes possui exemplares únicos, existem normas dentro da DIORA que permitem o empréstimo interinstitucional. Existem dois tipos de empréstimo: um que é feito para as exposições internas que acontecem no prédio sede da Biblioteca Nacional e o empréstimo para exposições externas. Para uma obra sair da Biblioteca deve haver uma avaliação da Divisão e isso também requer um seguro. $\mathrm{O}$ bibliotecário Luís Antônio explica como funciona esse empréstimo:

Para emprestar uma obra para uma entidade do Brasil, demora seis meses. Porque tem que ter uma avaliação, tem que ter um laudo do IPHAN. A Ana Virgínia é quem faz a avaliação do valor da obra. Ela é quem estima o valor da obra. Este valor é baseado no valor de raridade e no valor da obra como parte da coleção da Biblioteca Nacional. A obra não tem um valor só. Para essa obra ser emprestada para fora do país, o processo do pedido tem a duração de um ano. A entidade espera durante um ano para levar uma obra nossa para fora do país. Faz-se toda a avaliação sobre a procedência do pedido. O IPHAN tem que avaliar também; e vai fazer todos os questionamentos possíveis; tem que conhecer o local, para quem vai, para onde vai. Para tentar garantir o retorno da obra para o Brasil, faz-se um seguro muito alto, na faixa dos milhares de reais. O seguro é alto para que eles tenham o cuidado em devolver. E até a seguradora toma mais cuidado. 
O nosso interesse não é o pagamento do seguro e sim que a obra retorne. Tanto porque o dinheiro do seguro não ficaria conosco. [informação verbal, 01/10/ 2009].

Dentro da Divisão de Obras Raras existem duas seções especiais chamadas “inferno" e “cemitério”.

Nós temos um "cemitério" e um "inferno". Não existe uma área específica do "inferno". São obras extremamente proibidas, obras que foram consideradas nefastas, repugnantes e que, em algum momento da história, foram objeto de censura e que hoje podem até não ter significado algum; pode ser até uma bobagem hoje, mas, por serem consideradas nefastas na época de publicação, foram destruídas, queimadas, proibidas, censuradas e poucos exemplares sobreviveram. Algumas obras são efetivamente repugnantes mesmo, e ainda continuam assim. Um exemplo é o Mein Kampf (Minha Luta), de Hitler, ainda proibida na Alemanha. Existe na Biblioteca Nacional, mas é proibida, não circula. Nós temos aqui um exemplar, editado em vida. Não é a primeira edição, mas é um exemplar publicado em vida, na Alemanha. Nós temos aqui na Divisão de Obras Raras. É um exemplo de obra do nosso "inferno". [Ana Virgínia, informação verbal, 30/9/2009]

A outra seção especial é o "cemitério", onde estão livros que alcançaram um estágio alto de deterioração e não podem ser manuseados; ficam em uma área só para eles.

Então nós temos um “cemitério”. O nosso “cemitério” é uma área mesmo, onde ficam todas as obras fora de consulta. Não é uma obra que está completamente podre, porém ela está num estágio tal que, se o leitor mexer, ele vai pegar a informação, mas ninguém poderá mexer depois dele naquele livro, pois o livro vai ficar todo embaralhado. Pedaços se perderão. Ele vai ler, vai virar a página, e acabou! Aquela parte ninguém mais lê. Então são livros que o leitor pega e a gente vai lá e vê: fora de consulta. E aí o leitor pergunta: "quando é que eu posso voltar?” E eu não sabia dizer. Por isso eu fiz o Projeto Fênix, que foi patrocinado pelo BNDES. Só que este projeto pretende contemplar cento e cinquenta obras. É caro! São trezentos e poucos mil reais para cento e cinquenta obras. Já é alguma coisa, mas vamos fazer mais que isto, pois estamos priorizando as obras de pequeno porte, que estão fora de consulta; obras que são exemplares únicos, que são as mais raras -e pequenas - porque eu podia colocar a questão assim: vamos alcançar cento 
e cinquenta folhas, cento e cinquenta obras porque estamos fazendo um cálculo pelo número de folhas. [Ana Virgínia, informação verbal, 30/9/2009]

Segundo a apresentação do Projeto Fênix: resgate da memória em papéis de trapos, que está disponível no site da Fundação Biblioteca Nacional, desde janeiro de 2004 foi identificada no acervo de Obras Raras da Biblioteca Nacional a Coleção de obras raras "fora de consulta", arrolando cento e vinte e nove obras, das quais oitenta e nove constituem exemplares únicos no acervo, perfazendo o total de trinta mil folhas impressas e insubstituíveis. A coleção foi inventariada por demanda, isto é, itens solicitados pelo leitor que não podem ser manuseados e examinados em função do extenso nível de deterioração de sua parte física. Esse projeto visa a garantir a qualidade de acesso a todo o acervo da Divisão de Obras Raras da Biblioteca Nacional.

Esse projeto é uma ação interdisciplinar envolve três setores da Biblioteca:

- Divisão de Obras Raras;

- Coordenação de Preservação;

- Coordenação de Microrreprodução.

Nem todas as obras do “cemitério” serão contempladas no Projeto Fênix. Além do levantamento por demanda, todos os livros do projeto tiveram a análise bibliológica efetivada. A intenção é contemplar todas as áreas do conhecimento, como livros de literatura, Medicina, História, Geografia, Arte, culinária, bruxaria, caligrafia e outras.

O critério de escolha para a restauração é a demanda. A obra vai para restauração apenas porque o livro não tem condição de ser manuseado. E a restauração na Biblioteca Nacional não é estética, como não deve ser nunca. O objetivo é dar manuseabilidade ao livro. Se o livro está comido de bicho, está cheio de furinhos, mas a folha está na íntegra, flexível, então ele não é restaurado, pois a restauração depõe contra o livro, desvaloriza o livro [raro]. Ela é a intervenção de alguém que não interagiu para a produção daquele livro. Essa intervenção desvaloriza o livro, porque ele perde sua característica original, a sua originalidade. Ele se torna um livro maquiado. A restauração só retarda o processo de envelhecimento, pois, como o livro é de matéria orgânica, ele vai "morrer”. [bibliotecária Ana Virgínia, informação verbal, 30/9/2009]

Todas essas obras do Projeto Fênix serão digitalizadas e disponibilizadas na Biblioteca Digital da Fundação biblioteca Nacional. 


\subsection{Preservação de Livros Raros na Biblioteca Nacional}

A Coordenadoria de Preservação - COP da Biblioteca Nacional do Rio de Janeiro é subordinada ao Centro de Processos Técnicos -CPT e é composta pelo Centro de Conservação e Encadernação e o Laboratório de Restauração. Segundo o documento Diretrizes de Preservação na Fundação Biblioteca Nacional, o conceito preservação abrange todas as ações que se destinam a salvaguardar e a recuperar as condições físicas dos suportes que contém informações, com vistas à permanência destes materiais para as futuras gerações. Na Biblioteca Nacional, a preservação é uma ação que envolve inúmeras atividades, incluindo-se: conservação preventiva, conservação reparadora e restauração.

Segundo o atual Coordenador de Preservação, Jaime Spinelli, essas diretrizes para preservação têm como universo de aplicação o Prédio Sede, o Prédio Anexo, a Casa da Leitura, a Divisão de Música, a Biblioteca Euclides da Cunha e os demais setores localizados no Prédio Gustavo Capanema. Inclui também a Coordenadoria Geral de Planejamento e Administração, situada no nono andar da rua Debret, e a Biblioteca Demonstrativa de Brasília, no Distrito Federal.

De acordo com as Diretrizes, as ações de preservação na Fundação Biblioteca Nacional visam a três pontos fundamentais de atuação:

1. Os prédios;

2. As coleções;

3. O acesso.

Em relação às atividades de preservação direcionadas ao prédio sede e seus anexos, as Diretrizes focalizam os seguintes aspectos:

- A política de tombamento do prédio sede pelo IPHAN;

- As condições estruturais e arquitetônicas do prédio sede;

- A otimização da ocupação dos espaços físicos que o compõem;

- O contingente operacional dos espaços físicos que o compõem;

- O aumento sistemático da carga elétrica;

- As condições de trânsito e escape do prédio sede em caso de sinistro;

- As instalações de equipamentos e instrumentos de combate a incêndio;

- As condições de segurança contra roubos e vandalismos; 
- A atuação da Coordenadoria da Brigada Contra Incêndio no treinamento de todos os funcionários quanto aos princípios básicos de primeiros socorros e de manuseio de extintores portáteis;

- A manutenção quanto à limpeza de calhas e do pára-raios no telhado do prédio;

- A assessoria de especialistas em incêndio e explosão do Corpo de Bombeiros do Rio de Janeiro;

- Na criação de uma equipe de funcionários da Biblioteca, com treinamento específico, que atuarão como brigadistas;

- A execução de exercícios de escape de pessoal do prédio, como elemento antipânico em caso real.

Em relação às atividades voltadas para a preservação das coleções, as Diretrizes visam aos seguintes aspectos:

- As condições de ambientação das áreas de guarda de acervos;

- As condições de limpeza destas áreas;

- As condições de armazenamento dos livros e documentos em suas áreas de guarda;

- As normas para cessão de obras para exposições nacionais e internacionais.

As ações que visam ao acesso, de acordo com as Diretrizes de Preservação, são realizadas diretamente na obra a ser preservada, tais como:

- Manuseio de livros e documentos;

- A reprodução de acervo;

- A transferência de suporte (microfilmagem e digitalização).

O conceito conservação para a Biblioteca Nacional é um conjunto de procedimentos que tem por objetivo melhorar o estado físico do suporte, aumentar sua permanência e lhe prolongar a vida útil, possibilitando, desta forma, o seu acesso por parte das futuras gerações.

O coordenador de preservação, Jayme Spinelli, em 1997, escreveu o manual A conservação de acervos bibliográficos e documentais, que está disponível no site da Fundação Biblioteca Nacional; indicado por ele em entrevista, "este manual serve como registro histórico de métodos de conservação aplicados na Biblioteca Nacional”. Esse será utilizado na presente pesquisa como fonte de informação sobre as práticas de 
conservação preventiva e corretiva adotadas na Biblioteca Nacional. Segundo Spinelli (1997, p. 11),

[...] o trabalho pretende mostrar a todos que participam da preocupação e responsabilidade de conservar uma importante parcela do patrimônio cultural, uma gama destes problemas que afetam a vida dos acervos bibliográficos e estudar e apresentar tratamentos técnicos específicos à permanência da integridade dos mesmos, dentro de uma ordenação lógica e com o apoio técnico-científico.

Dentro de uma perspectiva de Política de Conservação a longo-prazo, de acordo com Spinelli, medidas de rotina são tomadas, tais como:

- Formular um diagnóstico do estado geral de conservação da obra e uma proposta quanto aos métodos e materiais que poderão ser utilizados durante o tratamento;

- Documentar todos os registros históricos porventura encontrados, sem destruílos, falsificá-los ou removê-los;

- Aplicar um tratamento de conservação dentro do limite do necessário e se orientar pelo absoluto respeito à integridade estética, histórica e material de uma obra;

- Adotar a princípio de reversibilidade, que é o leitmotiv atual do desenvolvimento e aplicação do método de conservação em livros e documentos, pois é importante ter sempre em mente que um procedimento técnico, assim como determinados materiais, é sempre alvo de constantes pesquisas e que isto propicia um futuro técnico-científico mais promissor à segurança de uma obra.

\subsubsection{Centro de Conservação e Encadernação - CCE}

O Centro de Conservação e Encadernação - CCE, subordinado à Coordenadoria de Preservação, tem como objetivo a aplicação e a supervisão de atividades de conservação preventiva e de conservação reparadora (que também pode ser chamada de conservação curativa, como Silvana Bojanoski, chefe do CCE, chamou-a em entrevista). Segundo ela, são procedimentos de intervenção direta no acervo, não demandam muito tempo para serem executados e têm por objetivo central a estabilidade de danos.

Em relação ao histórico de controle de infestação de agentes bibliófagos, em seu manual, Spinelli (1997) destaca que, apesar do prédio sede da Biblioteca Nacional estar localizado em uma cidade de clima tropical como é a cidade do Rio de Janeiro, restringe 
o texto sobre controle de proliferação de pragas aos insetos e roedores. Sobre o controle de insetos, a preocupação "em escala macro teve seu início no final da década de 1940, quando foi levado a efeito o projeto de instalação de quatro câmaras destinadas à fumigação do acervo da Biblioteca Nacional”. Essas câmaras estão localizadas no primeiro e quarto pavimentos das seções de Obras gerais e de Periódicos, respectivamente duas câmaras em cada seção.

Por ocasião da instalação das câmaras, o fumigante adotado era uma mistura de sulfeto e tetracloreto de carbono. Posteriormente as câmaras foram temporariamente desativadas, por motivo não registrado. Durante esse período, o tratamento preventivo ao aparecimento de organismos bibliófagos foi realizado na forma de pós inseticidas. Mais tarde, na década de 1980, houve uma reformulação de metodologia de desinfestação. Nessa ocasião foi estudada a proposta de aquisição de uma câmara de fumigação que utilizaria uma mistura de óxido de etileno, gás freon como biocida. A despeito das vantagens da câmara, a compra foi temporariamente suspensa. Mais recentemente, em 1985, foi implementado (sic) a reativação das quatro câmaras de fumigação. Dentre as modificações introduzidas, citam-se um sistema de exaustão e a utilização de inseticidas de uso domissitário autorizado pelo ministério da saúde. No momento, o produto utilizado é o DDPV diluído em etanol comercial, a 2\%. (SPINELLI, 1997, p. 31)

O controle de infestações de insetos domésticos, como moscas e baratas, é realizado por empresas privadas registradas na Fundação Estadual de Estudo do Meio Ambiente - FEEMA, e contratado através de processo de licitação pública. Por ocasião dos trabalhos de desinfestação, a Biblioteca Nacional é fechada ao público num período nunca inferior a 72 horas. O controle de proliferação de roedores é feito através de iscas raticidas à base de produtos cumarínicos, por empresas especializadas.

Como método de conservação preventiva, o Centro de Conservação e Encadernação destaca a higienização. Segundo Silvana Bojanoski, as câmaras de fumigação estão desativadas atualmente e, em casos isolados de infestação de fungos, é utilizado o álcool lysoforme.

A atividade de higienização, segundo o documento de Diretrizes de Preservação, é executada tanto na área interna do Centro de Conservação quanto in loco, realizada nas áreas de guarda dos acervos raros para onde são transportados às mesas de sucção 
de poeiras e técnicos treinados para este fim. Silvana destaca em entrevista que a higienização

[...] é um trabalho delicado, pois se trata de higienização de obras raras. Existe uma tendência nas instituições a destinar o trabalho de higienização às pessoas mais simples que não tem (sic) informação. E o Centro de Conservação vem tentando dar essa informação. Em relação à segurança do acervo tenta-se construir uma relação recíproca de confiança e preocupação com o acervo. A pessoa tem que ter essa noção de valor de memória e valor cultural da obra que está higienizando. Isso é muito importante, pois a pessoa sente-se motivada, porque a higienização é um trabalho muito braçal. [Silvana Bojanoski, informação verbal, 29/09/2009]

Outra atividade destinada à conservação preventiva é o acondicionamento de livros. No caso de livros de grande formato da Divisão de Iconografia, é utilizada uma capa de poliéster espesso e transparente que assegura a proteção desses livros quando manuseados.

Segundo Silvana, quando o acervo não está em boas condições, está com algum problema - capa solta, folhas soltas, lombada arrancada -, a providência a ser feita é colocar em um acondicionamento emergencial que consiste em usar um cadarço de algodão ou algo mais elaborado, como uma caixinha. Segundo ela, em determinado momento houve uma reclamação da chefe da Divisão de obras raras, que "o acervo estava virando um acervo de caixinhas”. Essa reclamação foi levada em consideração, pois o bibliotecário muitas vezes identifica o livro pela capa, por características que ele conhece e com isso recupera o livro mais rápido na estante. Na opinião dela, quem visita as obras raras sabe que é uma coleção muito bonita, com encadernações belíssimas e luxuosas, e com o acondicionamento em caixinha prejudica a estética da coleção.

Depois de muitas discussões, o conservador-restaurador Jayme Spinelli desenvolveu um tipo de acondicionamento que deixa a lombada visível, protegendo a capa e os cortes do livro. Silvana destaca que o material utilizado tem boa dobra e preço acessível, comparado com o outro, e, por isso, optaram por esse tipo de acondicionamento. E enfatiza que em casos extremos, em que o estado de deterioração está muito avançado, opta-se pela caixinha em formato de cruz, o antigo formato. 
Figura 3: Novo tipo de acondicionamento - vista lateral e vista superior.
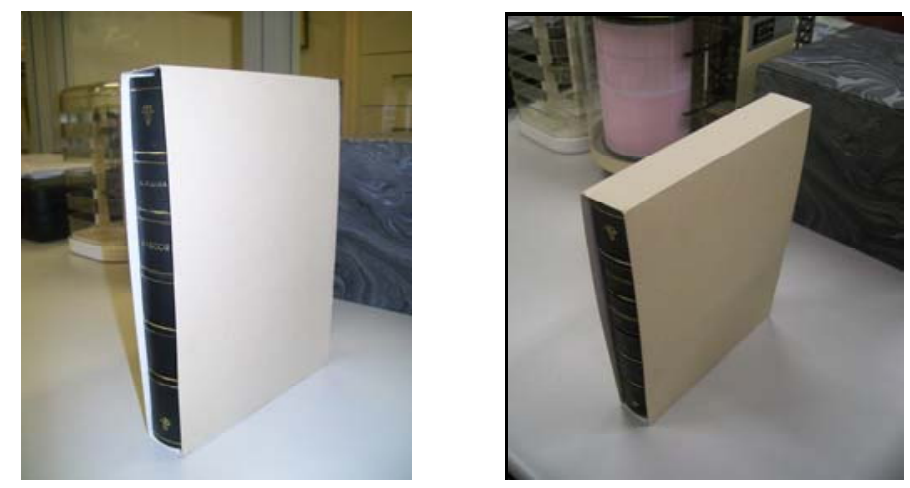

A conservação reparadora, também exercida pela Equipe técnica do Centro de Conservação e Encadernação, tem como atividades, segundo as Diretrizes de Preservação:

- Execução de diagnósticos das obras através de formulários específicos;

- Remendos de folhas;

- Consolidação de capas;

- Enxertos;

- Reestruturação de lombadas;

- Remoção de sujidades aderidas dos suportes (uso de pó de borracha ralada e/ou o uso de instrumentos de pontas para a retirada de excrementos ou corpos estranhos);

- Preparação do miolo dos livros para a encadernação;

- Encadernação de capa dura e brochuras;

- Douração de lombadas;

- Execução de acondicionamento para obras, como: caixas em cruz, caixas com cadarço para livros e periódicos; caixas port-fólio para álbuns fotográficos e livros de grandes formatos; passe-partouts; pastas, etc.

Das atividades citadas acima, a encadernação exercida no Centro de Conservação e Encadernação é destina às Obras gerais e aos Periódicos. A atividade de douração antes era feita com o componedor manual; hoje é utilizada, com mais frequência, uma máquina de douração. 
Figura 4: Demonstração de douração com componedor manual e atual máquina de douração.
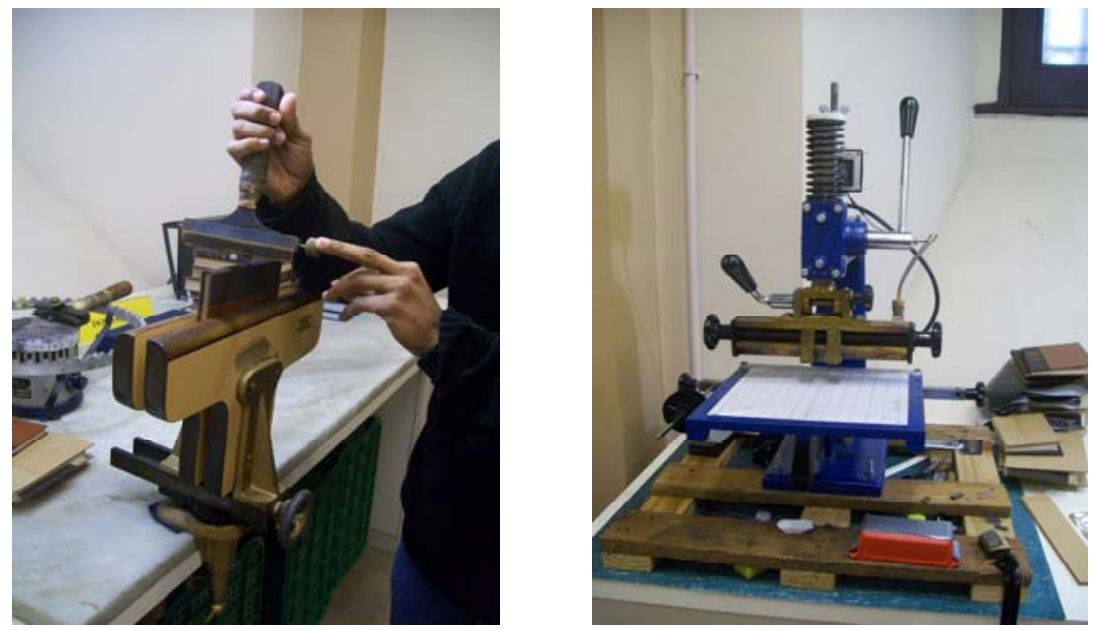

\subsubsection{Laboratório de Restauração}

O que diferencia o Centro de Conservação e Encadernação do Laboratório de Restauração são as atividades exercidas por ambos. Este faz uso de procedimentos aquosos e aquele de procedimentos a seco. Estão localizados no primeiro andar do prédio sede, em salas separadas. O Centro de Conservação é responsável pela higienização e conservação de todo o acervo da Biblioteca Nacional. Segundo a atual chefe do Laboratório de Restauração, Tatiana Ribeiro Christo,

[...] o Centro de Conservação e Encadernação tem uma responsabilidade maior em relação ao Laboratório por ter que responder a todos os setores, não só a Coordenadoria de acervos especializados, responsáveis pelos acervos mais antigos. A Restauração tem se dedicado à recuperação desse acervo antigo, especializado, enquanto que a Conservação tem o compromisso de interferir, por exemplo, na maneira como os leitores manuseiam os livros. Não é responsabilidade da Restauração ficar ali, orientando e educando as pessoas. Já o Centro de Conservação tem responsabilidade maior e abrangente de educar essas pessoas e tentar minimizar a degradação por causa do manuseio. [informação verbal, 30/09/2009] 
De acordo com as Diretrizes de Preservação, quando um livro ou documento plano raro já está em adiantado estado de deterioração, são adotadas técnicas de restauração. Restauração, para a Biblioteca Nacional, é um conjunto de procedimentos que visa a recuperar, o máximo possível, o seu estado original. São realizadas intervenções de tratamento item-por-item.

Devido à história da instituição e da formação do acervo, a Biblioteca Nacional possui obras em sério estado de degradação que necessitam de um tratamento de recuperação e melhoramento do estado das fibras do papel. No Laboratório de Restauração são adotados critérios estéticos e históricos; segundo as Diretrizes, estes dão base às ações técnicas que serão executadas pelos restauradores, como:

- Registros diagnósticos e fotográficos de antes, durante e depois de todos os tratamentos a serem efetuados;

- Reversibilidade de todas as ações técnicas executadas sobre as obras;

- Atenção à compatibilidade dos novos materiais e à obra em tratamento;

- Execução dos testes prévios de solubilidade de tintas utilizadas em obras, antes de qualquer intervenção de tratamentos aquosos;

- Reconstituição dos suportes originais na Máquina Obturadora de Papel (MOP);

- Encadernação e/ou restauração de encadernação de época com matérias especiais e seguindo normas e procedimentos técnicos precisos, na maioria das vezes frutos de intensa pesquisa;

- Confecção dos acondicionamentos necessários a cada caso.

Atualmente, o Laboratório é formado por uma equipe de quatorze pessoas, sendo sete servidores do quadro da instituição, quatro terceirizados e três contratados especificamente para o Projeto Fênix. Existe uma previsão de concurso público para substituir essa demanda que está preenchida por funcionários terceirizados.

Quanto aos critérios adotados para escolha de livros que serão ou não encaminhados para a equipe do Laboratório de Restauração, Tatiana responde:

Não existem normas, documentos, critérios pré-estabelecidos para que um livro venha para o Laboratório de Restauração. Quanto ao que deve ser ou não restaurado, quais são os critérios? A verdade é que a Biblioteca Nacional, por ser a primeira da América Latina, não dá pra você 
diagnosticar nove milhões de peças e estabelecer prioridades. [Tatiana Ribeiro Christo, informação verbal, 30/09/2009]

Segundo Tatiana, a função do Laboratório de Restauração dentro da instituição é atender, recuperar e restaurar não só acervos da Divisão de Obras Raras, que nesse momento tem o projeto financiado pelo BNDES, mas também atender a outros setores.

Nós estamos aqui para priorizar acervos de memória como Divisão de Iconografia, Divisão de obras raras, Divisão de música, todos subordinados à Coordenadoria de acervos especializados. Tenta-se, na medida do possível, apesar da atual atenção dada à Divisão de obras raras, por conta desse projeto que tem uma meta a cumprir, o Laboratório acaba priorizando uma maior parte da equipe para atingir a meta, mesmo que tenha contratado três pessoas só para esse projeto. [Tatiana Ribeiro Christo, informação verbal, 30/09/2009]

De acordo com Tatiana, a rotina de trabalho do Laboratório está geralmente direcionada a projetos que são desenvolvidos pelas Divisões de acervos especializados:

[...] o laboratório tem atendido a todos os setores; houve um tempo em que o trabalho estava direcionado mais à iconografia, devido a um projeto de digitalização. E em seguida um projeto de cartografia, com o objetivo de recuperar o acervo cartográfico, que durou 2 anos. E agora, terminando o Projeto Fênix, nós temos o interesse de recuperar o acervo da Divisão de Manuscritos. Já faz algum tempo que não recuperamos documentos manuscritos. O tipo de dano sofrido pelo manuscrito é diferente dos livros impressos; está muito ligado à degradação das tintas. O tipo de procedimento que usávamos para recuperar, hoje em dia está em desuso. Sabemos que já existem procedimentos mais atuais, mais avançados. Então o desejo é dedica-se à Divisão de Manuscritos futuramente. [informação verbal, 30/09/2009]

Existe sempre uma comunicação entre os curadores e chefes das Divisões com o Laboratório de Restauração. Segundo a chefe do Laboratório, existe certa importância nesse diálogo permanente entre chefias, pois cada vez mais os curadores entendem qual é o tipo de trabalho realizado na Restauração e também a equipe do Laboratório passa a entender cada vez mais o tipo de acervo que está recuperando. 
Quando o material não faz parte de qualquer projeto específico para dar entrada no Laboratório, esse deve estar em estado avançado de degradação, e pode ter sido identificado no momento em que é feita a higienização do acervo ou por indicação dos curadores. Tatiana esclarece a postura do Laboratório diante dessa situação:

[...] os curadores conhecem bem o acervo pelo qual são responsáveis. Quando um conjunto de volumes está bastante degradado, o chefe da Divisão solicita os serviços da Restauração. O Laboratório verifica se existem condições materiais e técnicas. Porque às vezes o trabalho é tão complexo que não se dispõem, naquele momento, de conhecimento técnico para resolver o caso. Então o serviço não irá acontecer de imediato. É importante ter a sensibilidade de dizer sim quando é caso de Restauração, mas tecnicamente não se dispõe de equipamento ou profissional especializado para o caso. [informação verbal, 30/09/2009]

Tanto no Centro de Conservação e Encadernação como no Laboratório de Restauração é realizada a encadernação de livros do acervo. A diferença é que o Centro de Conservação e Encadernação se preocupa mais com obras gerais e periódicos, que são, na maioria das vezes, livros contemporâneos. Segundo Tatiana, o Centro de Conservação está criando uma estrutura para a restauração de encadernações não só de obras contemporâneas, mas também para obras do século XIX.

Já a encadernação que é feita no Laboratório de Restauração é dedicada a livros raros que estão muitas vezes desprovidos de encadernação original ou de outra encadernação que tenha recebido ao longo de sua existência. Desde 1987, a Biblioteca Nacional faz uso da encadernação flexível de pergaminho. Em seu texto A adoção da encadernação flexível em pergaminho em obras raras restauradas na Biblioteca Nacional do Rio de Janeiro, Tatiana Ribeiro Christo ([2008], p. 3) menciona que:

[...] após a restauração do bloco de texto, optou-se pela encadernação flexível em pergaminho não só pelos aspectos mencionados acima, bem como porque atendia ao princípio da reversibilidade, ou seja, era possível desfazer a encadernação de modo fácil sem prejuízo ao bloco de texto e pela facilidade de encontrar no Brasil materiais de boa qualidade para sua execução. (p. 2)

[...] Este modelo, pela sua praticidade, está em conformidade com o conceito de conservação preventiva o qual contempla a recuperação de uma grande quantidade de obras em um curto prazo de tempo e atende a novas demandas quanto à agilização de processos de microfilmagem e digitalização para 
assegurar o acesso à informação pelos pesquisadores e usuários da Biblioteca Nacional.

Figura 5: Modelos de Encadernação Flexível de pergaminho
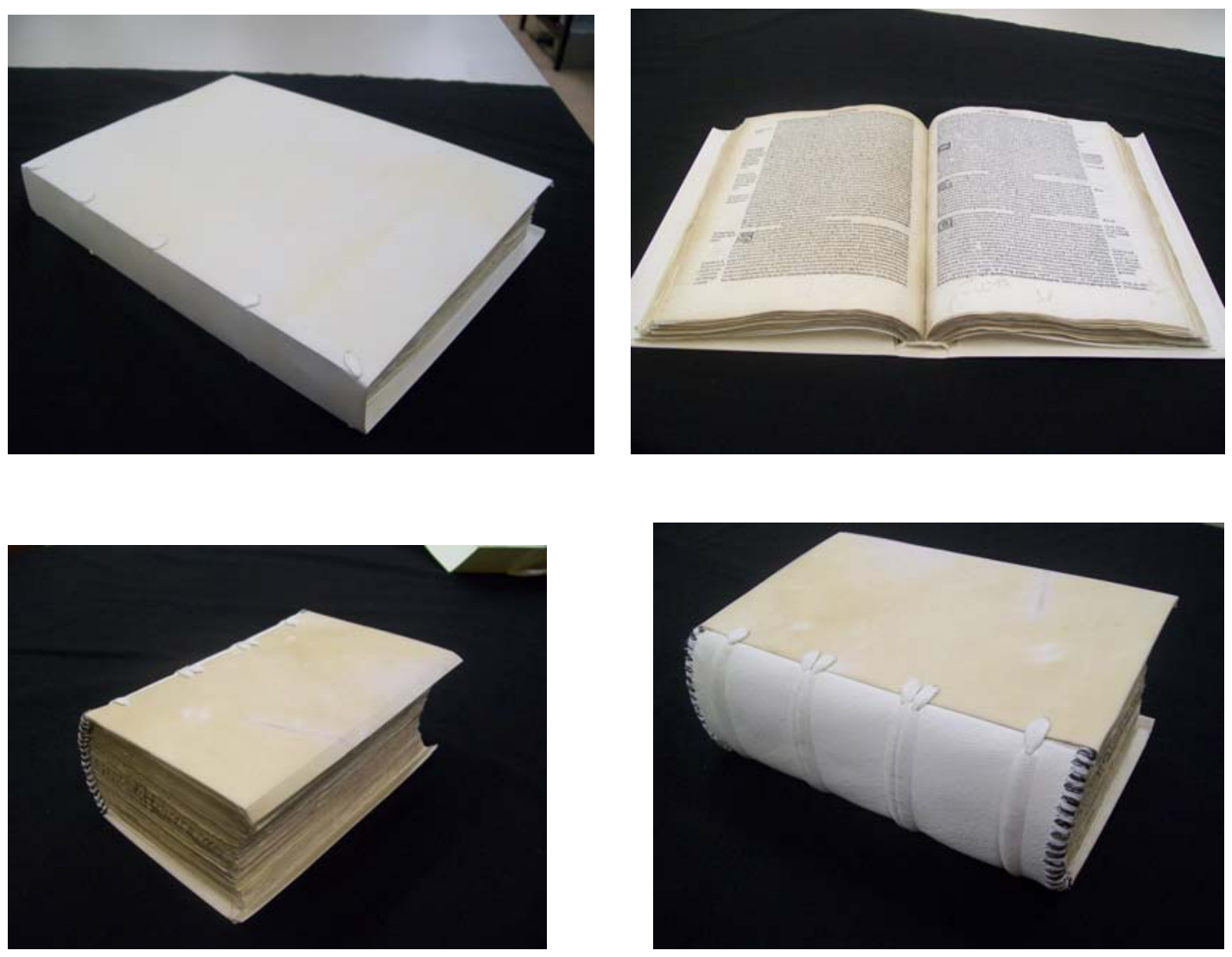

Dentro do universo da preservação, na Biblioteca Nacional existe também a Coordenadoria da Brigada Contra Incêndio, chefiada também por Jayme Spinelli. Em entrevista, Spinelli relata que "nunca houve casos de desastres ou enchentes no prédio sede da Biblioteca Nacional”. Essa Coordenadoria foi implantada em 2003, é composta pela Brigada de incêndio e pela Brigada voluntária; pelo menos dois funcionários de cada Divisão são responsáveis, em situação de risco, por coordenar os serviços no momento que lhes forem solicitados. Além disso, todos os funcionários recebem treinamentos periódicos de como utilizar os extintores de incêndio.

Em relação à segurança do acervo, em setembro de 2006 foram instituídos procedimentos relativos à entrada e saída de material na Biblioteca Nacional:

É livre a entrada dos seguintes materiais:

- Fotocópia de diários oficiais;

- Bibliografias, impressas ou em fotocópias; 
- Papel de rascunho em folhas reaproveitadas;

- Folhas impressas da Internet;

- Questionários ou exercícios, impressos ou em fotocópias;

- Documentos pessoais: declarações, cópia de identidade/CPF, imposto de renda, passaporte, etc.;

- Cadernos, blocos, agendas, lápis, lapiseira, borracha e apontador.

Não é permitida a entrada de:

- Bolsas, pochetes, pastas ou volumes;

- Originais ou fotocópias de livros, jornais, revistas, fotos, mapas, gravuras, desenhos;

- Marcador de texto, caneta, corretivo;

- Alimentos e bebidas;

- Aparelhos eletro-eletrônicos: mp3 player, discman, scanner;

- Arma de fogo e objetos cortantes;

- Bolsa ou pasta de laptop.

Material condicionado a autorização:

- Notebook, palm top, laptop, pen drive, CD, disquete, DVD, cabo, fio de extensão, bateria, teclado, mouse, gravador e lupa;

- Máquina fotográfica e filmadora (com agendamento prévio da reprodução);

- Calculadora;

- As exceções, tais como obras ou capítulos de livros (originais ou fotocópias) necessários à pesquisa do usuário, com fins de cotejamento ou tradução, serão avaliadas pelas áreas de acervo;

- As autorizações serão concedidas pelas áreas de acervo, carimbadas e com assinaturas legíveis;

- Celulares deverão permanecer desligados ou no modo silencioso. Seu uso é restrito às áreas externas.

Também foi implantado o Sistema de Segurança Eletrônica do Prédio Sede da Biblioteca Nacional. O sistema de segurança está dividido em duas partes: 
1. Controle de acesso:

O controle de acesso às dependências do edifício é feito através de roletas em plataforma metálica e porta para passagem de deficientes físicos. O sistema utiliza crachás magnéticos que fazem o controle de acesso de leitores, visitantes e funcionários, além do controle de portas por fecho magnético;

\section{Monitoramento:}

O monitoramento dos espaços do edifício é feito por circuito interno de TV com câmeras fixas e câmeras Dome. O prédio tem 70 câmeras espalhadas por todos os espaços internos. As imagens são gravadas em DVD e armazenadas por 30 dias. Também foram instalados sensores de movimento por IR wireless em locais estratégicos e sensores de abertura de portas.

O Núcleo de Arquitetura da Fundação Biblioteca Nacional procurou não atingir a estrutura arquitetônica do edifício, utilizando tecnologia atual e flexível. A Biblioteca Nacional recebe em média, por mês, 8.500 usuários e 1.300 visitantes; contando com o número de funcionários, isso gera um fluxo muito grande de pessoas dentro do prédio sede, o que exige, por medida de segurança e preservação do acervo, a manutenção de uma estrutura de segurança e vigilância eficiente. 


\section{Conclusão}

O livro raro é um objeto tão específico que possui valores intrínsecos e extrínsecos tão pertencentes a ele que seria impossível relatar qualquer tipo de estudo sem antes conhecer o discurso da Biblioteconomia de livros raros. E, por ser considerado patrimônio intelectual da humanidade, é imprescindível a busca por métodos de preservação do mesmo.

É interessante notar que essa preocupação quanto à organização e preservação de livros raros há quase setenta anos, continua até hoje, principalmente quando se fala em termos de Brasil. A literatura sobre Biblioteconomia de livros raros é escassa e as fontes geralmente são estrangeiras. Mas os atuais estudos são de grande valia para curadores de acervos preciosos e raros espalhados pelo Brasil.

Atividades voltadas para a preservação deveriam ser uma das prioridades de uma biblioteca de memória, pois estão relacionadas com o acesso e o uso de materiais que compõem o acervo. Não é luxo; é uma atividade necessária, considerando que os livros servem para serem lidos, e pessoas os manipulam de qualquer forma, o que leva à deterioração inevitável de seus materiais.

A análise dos dados comprovou que a instituição Biblioteca Nacional, mesmo tendo que buscar recursos financeiros em entidades particulares, não mede esforços para a preservação da memória intelectual do Brasil.

A conversa com a especialista em livros raros, Ana Virgínia Pinheiro, esclareceu diversos pontos sobre os critérios de raridade bibliográfica adotados pela Biblioteca Nacional. Em 1989, Ana Virgínia publicou Que é livro raro, onde sua intenção era organizar uma metodologia para o estabelecimento de critérios. Ela não diz o que é raro. Segundo ela, em entrevista, foi feito um levantamento de todos os critérios que se conhecia na época, de acordo com ela um mais absurdo que o outro. Por exemplo, muitos critérios eram baseados na impressão de livreiros ou de um bibliófilo cujos critérios estão relacionados aos interesses de se colecionar o objeto livro.

Em entrevista, Ana Virgínia destaca que o trabalho foi um levantamento de todos os critérios praticados e, com “um olhar de bibliotecário”, ela classificou esses critérios em cinco abordagens, estas já citadas no capítulo sobre Biblioteconomia de livros raros. 
A Biblioteca Nacional procurou estabelecer seus próprios critérios de raridade bibliográfica, baseados exclusivamente no fator falta de espaço para armazenagem. Então, os critérios adotados pela Biblioteca Nacional não servem para qualquer outra biblioteca. Bibliotecas podem procurar a Biblioteca Nacional através PLANOR - Plano Nacional de Recuperação de Obras Raras, que tem como objetivos avaliar e orientar instituições que possuem acervos raros e preciosos.

Impressões tidas durante a visita feita ao prédio sede, localizado na cidade do Rio de Janeiro, foram todas direcionadas a uma só frase: preservar para permitir o acesso. A consciência de preservação para a garantia do acervo futuro, tanto dos funcionários aos visitantes e leitores, ficou evidente no sentimento coletivo de todos, que de alguma maneira usufruíam do privilégio de ter um acervo inigualável à sua disposição.

É evidente a importância de todas as atividades realizadas na instituição, dos serviços gerais ao cadastro de usuários na entrada do edifício; da obrigatoriedade do uso de crachá durante a permanência no prédio e das câmeras que focalizavam documentos escritos por usuários nas mesas à discrição dos funcionários; o cuidado e a consciência da responsabilidade que os mesmos tinham por cada informação fornecida a respeito das atividades exercidas nos setores.

Esse texto não seria escrito desta maneira se a visita ao prédio sede da Biblioteca Nacional não tivesse sido realizada. Não foi possível fazer uma pesquisa exaustiva sobre a história do livro impresso, pois o tempo dedicado à pesquisa não foi satisfatório. É sabido que uma pesquisa que envolva a história da produção do conhecimento humano, a evolução das diversas maneiras de formar e de desenvolver coleções de acervos preciosos e raros, a evolução de métodos que visam à preservação a longo prazo deve visar a conscientizar a sociedade da importância da preservação do original do livro impresso.

A importância, para o pesquisador, de ter contato com a fonte primária da informação de seu interesse revela-se na qualidade dos resultados obtidos na pesquisa. E, no caso do Brasil, hoje, caracterizado como um país em desenvolvimento econômico, o uso de fontes primárias em pesquisa pode acelerar o seu desenvolvimento. E isso só será possível futuramente se a sociedade, a instituição de guarda e o governo tiverem consciência do valor da preservação de seu patrimônio bibliográfico e documental. 


\section{Referências}

ANDRADE, R. H. R de; CANTALINO, M. G. N. A raridade como questão epistemológica e pólitca: um novo paradigma para curadores de acervos especiais. Anais da Biblioteca Nacional, rio de janeiro, v. 123, 2003.

ANTUNES, Cristina. Memórias de uma guardadora de livros. São Paulo: Imprensa Oficial do Estado; Florianópolis, SC: Escritório do Livro, 2004. (Coleção Memória do Livro).

ARAÚJO, Emanuel. A construção do livro: princípios da técnica de editoração. Rio de Janeiro: Nova Fronteira, 1986.

ARCHER, Horace R. Rare book collections: Some theoretical and practical suggestions for use by librarians and students. Chicago: Ala, 1965.

ARCHER, Horace R. Introduction. In: — Rare book collections: Some theoretical and practical suggestions for use by librarians and students. Chicago: Ala, 1965. p. 1-3.

BANDEIRA, Suelena P. O mestre dos livros: Rubens Borba de Moraes. Brasília, DF: Briquet de Lemos, 2007.

BAUGHMAN, Roland O. Organization of a collection. In: ARCHER, Horace R. Rare book collections: Some theoretical and practical suggestions for use by librarians and students. Chicago: Ala, 1965. p. 35-50.

BIBLIOTECA NACIONAL. (Brasil). Relatório de Gestão 2004. Disponível em:

$<$ http://www.bn.br/portal/?nu_pagina=10 >.

BIBLIOTECA NACIONAL. (Brasil). Plano Nacional de Recuperação de Obras Raras Planor. Critérios de raridade adotados pela Fundação Biblioteca Nacional. Disponível em: < http://www.bn.br/planor/documentos.html >.

BIBLIOTECA NACIONAL. (Brasil). Projeto Fênix. Disponível em: < http://www.bn.br/portal/arquivos/pdf/Fenix_Divulgacao.pdf $>$.

BIBLIOTECA NACIONAL. (Brasil). Norma $n^{\circ}$ 01, de 02 de maio de 2006, para reprodução do acervo. Disponível em: < http://www.bn.br/portal/arquivos/pdf/norma.pdf $>$.

BIBLIOTECA NACIONAL. (Brasil). Tabela de Emolumentos para Preservação do Acervo Pessoa Física - Uso de acervo especial. Disponível em: < http://www.bn.br/portal/arquivos/pdf/tabelaEmolumentosEspecial.pdf > .

BIBLIOTECA NACIONAL. (Brasil). Centro de Processos Técnicos - CPT. Coordenadoria de Preservação - COP. Diretrizes de preservação na Fundação 
Biblioteca

Nacional.

Disponível

em:

<http://www.fbn.br/portal/arquivos/pdf/Diretrizes.pdf >. Acesso em: 8 set. 2009.

BIBLIOTECA NACIONAL. (Brasil). Disponível em: < http://www.fbn.br/portal/ > .

BIBLIOTECA Átila Almeida de volumes raros reabre com nova política de organização e higienização. Universidade Estadual da Paraíba. Disponível em: < http://www.uepb.edu.br/bc/content/view/50>. Acesso em: 16 ago. 2009.

A BIBLIOTECA digital de obras raras e especiais. Universidade de São Paulo. Disponível em:< http://www.obrasraras.usp.br/ >.Acesso em: 17 jul. 2009.

BOLETIM Informativo do Planor, Rio de janeiro, ano 10, n. 13, 2006. Disponível em: < http://www.bn.br/planor/BoletinsPLANOR/Planor_Boletim13.pdf >.

BOLETIM Informativo do Planor, Rio de janeiro, ano 10, n. 14, 2006. Disponível em: < http://www.bn.br/planor/BoletinsPLANOR/Planor_Boletim14.pdf >.

BRASIL. Decreto n. 5.038 de 7 de abril de 2004. Aprova o Estatuto e o Quadro Demonstrativo dos Cargos em Comissão e das Funções Gratificadas da Fundação Biblioteca Nacional - BN, e dá outras providências. Diário Oficial [da] República Federativa do Brasil, Brasília, 8 abr. 2004.

CAMPELLO, Bernadete. Introdução ao controle bibliográfico. 2. ed. Brasília, DF: Briquet de Lemos, 2006.

CARVALHO, Maria da C.; FERNANDES, Cleide. Conservação de livros raros: relato de uma experiência pedagógica. Perspectiva em Ciência da Informação, Belo Horizonte, v. 11, n. 1, p. 95-101, jan./abr. 2006.

CASSARES, Norma Cianflone. Como fazer conservação preventiva em arquivos $e$ bibliotecas. São Paulo: Arquivo do Estado e Imprensa Oficial, 2000. (Projeto Como fazer, 5).

CARTERI, Karin Kreismann. O livro e os critérios de raridade. Revista Museu: cultura levada a sério [online], 2005. Disponível em: < http://www.revistamuseu.com.br/artigos/art_.asp?id=5484 >. Acesso em :8 set. 2009.

CAVE, Roderick. Rare book librarianship. London: C. Bingley, 1976.

CHRISTO, Tatiana R. A adoção da encadernação flexível em pergaminho em obras raras restauradas na Biblioteca Nacional do Rio de Janeiro. 2008. Disponível em: < http://www.bn.br/portal/arquivos/pdf/Enc_Flex_BN.pdf >. Acesso em. 8/9/2009.

DESCRIPTIVE Cataloging of Rare Books. 2nd edition. The Library of Congress. 19952001. Disponível em: <http://www.itsmarc.com/crs/rare0170.htm>. Acesso em: 16/07/2009. 
FEBVRE, Lucien P. V.; MARTIN, Henri J. O aparecimento do livro. Lisboa: Fundação Calouste Gulbenkian, 2000.

FRIEIRO, Eduardo. Os Livros nossos amigos. Belo Horizonte: P Bluhm, 1941.

FURTUNATO, Sandro. As manias de cada um e o que faz de um livro uma raridade. 18 de fevereiro de 2008. Blog Bibliofilia. Disponível em:< http://www.sandrofortunato.com.br/salgo/2008/02/18/as-manias-de-cada-um-e-o-quefaz-de-um-livro-uma-raridade/>. Acesso em: 17 jul. 2009.

GAUZ, Valéria (Coord.). Segurança em acervos raros. Rio de Janeiro: Fundação Biblioteca Nacional, 1994.

GAUZ, Valéria. Nova perspectiva para a aquisição de livros raros e coleções especiais. Agosto, $2006 . \quad$ Disponível em:

http://www.ofaj.com.br/colunas_conteudo.php?cod=266 >. Acesso em: 8 set. 2009.

GAUZ, Valéria. Educação para bibliotecários de livros raros. Novembro, 2006. Disponível em: < http://www.ofaj.com.br/colunas_conteudo.php?cod=277 >. Acesso em: 8 set. 2009.

GAUDÊNCIO JUNIOR, Norberto. A herança escultórica da tipografia. São Paulo: Rosari, 2004.

GUIMARÃES, Lygia. Conservação e restauração de documentos em suporte de papel. In: Conservação de acervos. Rio de Janeiro: Museu de Astronomia e Ciências AfinsMAST, 2007. (MAST Colloquia, 9).

HAZEN, Dan C. Desenvolvimento, gerenciamento e preservação de coleções. Planejamento de preservação e gerenciamento de programas. 2. ed. Rio de Janeiro: Projeto Conservação Preventiva em Bibliotecas e Arquivos, 2001. p. 7-15.

HALLEWELL, Laurence. O livro no Brasil: sua história. São Paulo: T A Queiroz, 1985. 693 p. (Coleção coroa vermelha: estudos brasileiros, 6).

HERKENHOFF, Paulo. Biblioteca nacional: a história de uma coleção. 2.ed. Rio de Janeiro: Salamandra, 1996.

KREMER, Jeannette M.; GOMES, Sônia C.; SILVEIRA, Julia G. Avaliação das condições de preservação e do estado de conservação da coleção da Biblioteca da Escola de Biblioteconomia da UFMG. Revista da Escola de Bibloteconomia, UFMG, Belo Horizonte, v. 21, n. 1, p. 136-173, jan./jun. 1992.

INTERNATIONAL Standard Bibliographic Description for Older Monographic Publications - $\quad$ ISBD $\quad$ (A). Disponível em: < http://catalogue.nla.gov.au/Record/1576211>. 
JUNIOR SPINELLI, Jayme. Conservação de acervos bibliográficos documentais. Rio de Janeiro: Fundação Biblioteca Nacional, 1997. (Documentos técnicos, 1). Disponível em: < http://www.fbn.br/portal/?nu_pagina=56 >. Acesso em: 8 set. 2009.

MINDLIN, José E. Uma vida entre livros: reencontros com o tempo. São Paulo: EDUSP, Companhia das Letras, 1997.

MANSUÊTO, Luís. Inpa concentra maior acervo de obras raras sobre a Amazônia. Jornal da Ciência, 12 de dezembro de 2006. Disponível em:< http://oserbibliotecario.blogspot.com/2006/12/inpa-concentra-maior-acervo-delivros.html>. Acesso em: 16 jul. 2009.

MELLO, José B. Sintese historica do livro. Rio de janeiro: Leitura, 1972.

MEY, Eliane Serrão A. Introdução a catalogação. Brasília: Briquet de Lemos, 1995.

MCMURTRIE, Douglas C. Livro: impressão e fabrico. Lisboa: Fundação Calouste Gulbenkian, 1969.

MORAES, Rubens Borba de. O bibliófilo aprendiz. 4. ed. Brasília: Briquet de Lemos, 2005.

MORAES, Rubens B. de. Livros e bibliotecas no Brasil colonial. 2. ed. Brasília: Briquet de Lemos, 2006.

NARDINO, Anelise T. D.; CAREGNATO, Sônia E. O futuro dos livros do passado: a biblioteca digital contribuindo na preservação e acesso às obras raras. Em Questão, Porto Alegre, v. 11, n. 2, p. 381-407, jul./dez. 2005.

NATHANSON, D; VOGT-O'CONNOR, D. What makes a book rare? The Conserve 0 Gram, Washington, n. 19/1, jul. 1993. Disponível em: < http://www.nps.gov/history/museum/publications/conserveogram/19-01.pdf >. Acesso em: 6 jul. 2009.

OGDEN, Sherelyn. Planejamento e prioridades. In: OGDEN, Sherelyn; GARLICK, Karen. Planejamento e prioridades. 2. ed. Rio de Janeiro: Projeto Conservação Preventiva em Bibliotecas e Arquivos, 2001a.

OGDEN, Sherelyn. Política de desenvolvimento de coleção e preservação. In: OGDEN, Sherelyn; GARLICK, Karen. Planejamento e prioridades. 2. ed. Rio de Janeiro: Projeto Conservação Preventiva em Bibliotecas e Arquivos, 2001b.

OGDEN, Sherelyn. Administração de emergências. 2 ed. Rio de Janeiro: Projeto Conservação Preventiva em Bibliotecas e Arquivos , 2001c.

PINHEIRO, Ana Virgínia T. P. A Biblioteconomia de livros raros no Brasil: necessidades, problemas e propostas. Revista Biblioteconomia e Comunicação, Porto Alegre, UFRGS, v. 5, p. 45-50, jan./dez. 1990. 
PINHEIRO, Ana Virgínia T. P. Que é livro raro? uma metodologia para o estabelecimento de critérios de raridade bibliográfica. Rio de Janeiro: Presença Edições; Brasília: INL, 1989.

PINHEIRO, Ana Virgínia T. P. Do labirinto ao invisível: a história do livro raro no Brasil. Disponível em: <http://www.scribd.com/doc/7104187/T020AnaVirginia>. Acesso em: 12 ago. 2009.

PINHEIRO, Ana Virginia. Livro raro: antecedentes, propósitos e definições. Publicado em 14 out. 2004. Disponível em: < http://bibliodesign.com.br/bibliodesign/bibliofilia/index.asp?idMateria=66 > . Acesso em: 6 jul. 2009.

PINHEIRO, Ana Virginia. A ordem dos livros na biblioteca: uma abordagem preliminar ao Sistema de Localização fixa. Rio de Janeiro: Interciência; Niterói: Intertexto, 2007.

PINHEIRO, Ana Virginia. Da Real Biblioteca à biblioteca Nacional. In: PEREIRA, Paulo R. D. Biblioteca Nacional (Brasil). Brasiliana da Biblioteca Nacional: guia das fontes sobre o Brasil. Rio de Janeiro: Fundação Biblioteca Nacional; Nova Fronteira, 2001b. p. 241-248.

PRADO, Heloísa de A. Organização e administração de bibliotecas. 2. ed. São Paulo: T A Queiroz, 1992.

RIZZINI, Carlos. O livro, o jornal e a tipografia no Brasil, 1500-1822: com um breve estudo geral sobre a informação. Rio de janeiro: Kosmos, 1946.

RODRIGUES, Márcia C.; PANCICH, Renata F. Obras raras: identificação e conservação, experiência da Universidade de Caxias do Sul. Transinformação, Campinas, v. 20, n. 3, p. 265-271, set./dez. 2008.

RODRIGUES, A. H.; CALHEIROS, M. F.; COSTA, P. da S. Análise biblilógica de livros raros: a preservação ao "pé da letra”. In: BIBLIOTECA NACIONAL. (Brasil). Anais da Biblioteca Nacional, Rio de Janeiro, 123, 2003. Disponível em: < http://www.bn.br/planor/documentos/anais_123_2003.pdf >.

SANT’ANA, Rizio Bruno. Critérios para a definição de obras raras. Revista Online da Biblioteca Prof. Joel Martins, Campinas, v. 2, n. 3, p. 1-18, jun. 2001.

SILVA, S. C. A. Algumas reflexões sobre preservação de acervos de arquivos e bibliotecas. Rio de Janeiro: Academia Brasileira de Letras, 1998.

SCHWARCZ, Lilia M. O livro dos livros da Real Biblioteca = The Royal library's book of books. São Paulo: Fundação Odebrecht, 2003. Edição bilíngue.

TIPÓGRAFOS. NET. Disponível em: < http://tipografos.net/livros-antigos/b-42.html $>$. 
TURRER, Rodrigo. Biblioteca mundial digital é uma torre de Babel eletrônica. Revista Época, Ed. 570, 17 de abril de 2009. Disponível em: < http://revistaepoca.globo.com/Revista/Epoca/0,„ERT68837-15220-68837-3934,00.html >. Acesso em: 17 jul. 2009.

VERGUEIRO, Waldomiro de C. S. Desenvolvimento de coleções. São Paulo: POLIS/APB, 1989

VALLE, Clarimar A. Subsídios para uma política de preservação e conservação de acervos em bibliotecas universitárias brasileiras. 1991. Dissertação (Mestrado em Biblioteconomia e Documentação) - Departamento de Biblioteconomia e Documentação, Universidade de Brasília, Brasília, 1991.

WYNNE, Majorie Gray. The nature and importance of rare books. In: ARCHER, Horace R. Rare book collections: Some theoretical and practical suggestions for use by librarians and students. Chicago: Ala, 1965. p. 4-10

WOLF 2nd, Edwin. The development of rare book collections in the United States. In: ARCHER, Horace R. Rare book collections: Some theoretical and practical suggestions for use by librarians and students. Chicago: Ala, 1965. p. 11-25

ZUÑIGA, Solange G. de. A importância de um programa de preservação em arquivos públicos e privados. Registro, ano 1, n. 1, p. 71-89, jul. 2002. 


\section{ANEXOS} Anexo A - Exemplo de ficha catalográfica com notas atualizadas e com acesso ao
livro digitalizado (link HTML)

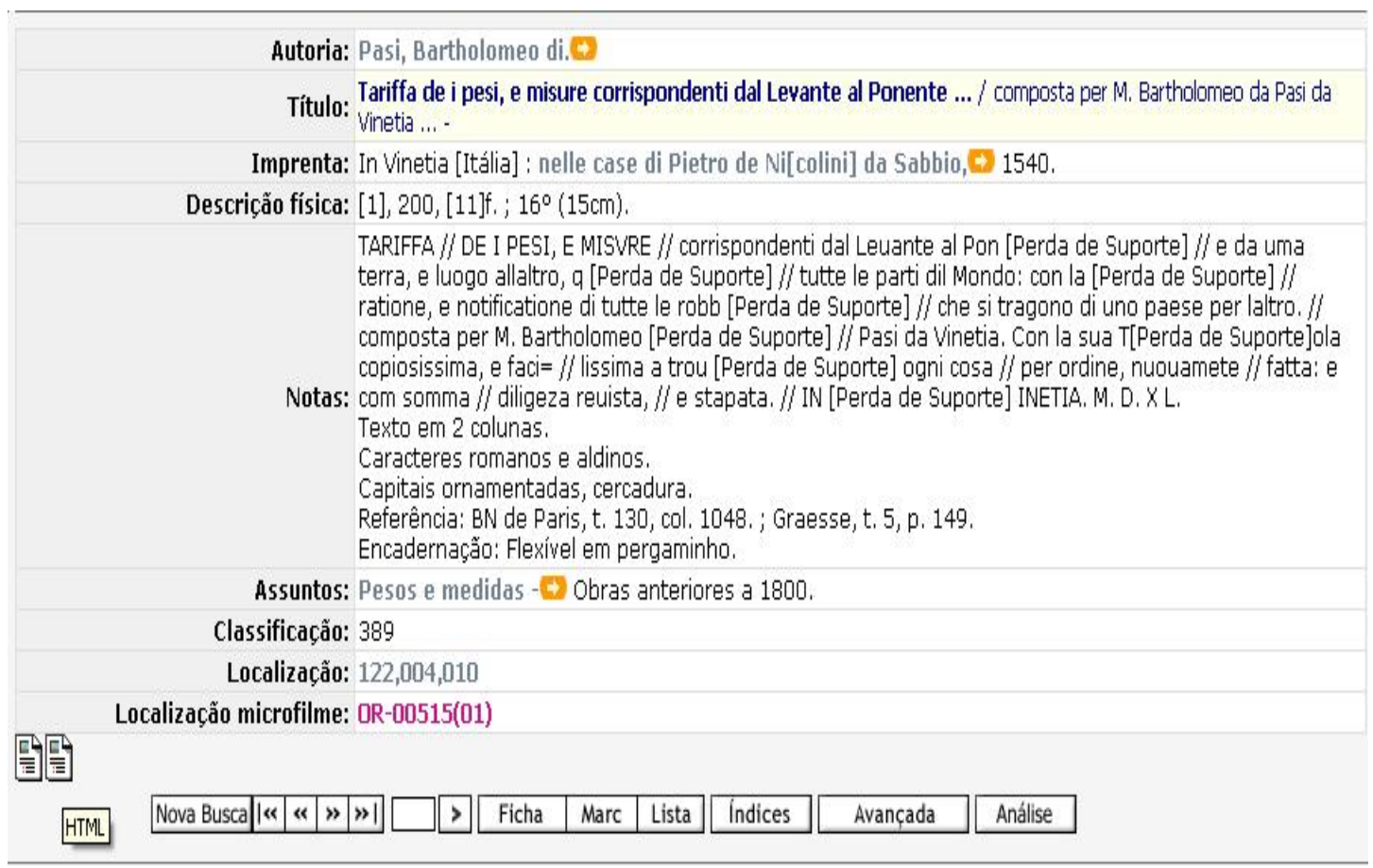




\section{Anexo B - Termo de Responsabilidade}

TERMO DE RESPONSABILIDADE PARA REPRODUÇĀO DE IMAGENS ${ }^{1}$

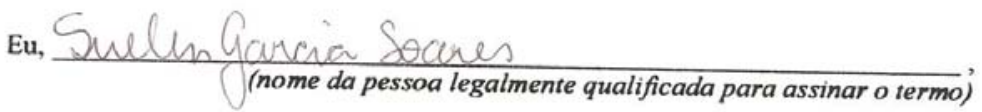

portador (a) da cédula de identidade $\mathrm{n}^{\circ}-2176368$ - DF

CPF n $002496111-63$, na qualidade de

$(X)$ pessoa fisica

( ) representante legal do (a)

(razẽo social da empresa)

CNPJ $n^{\circ}$ , domiciliado(a) à

QR 415 os 5 cara 2 -Samambaintherte-DE

(no caso de pessoa fisica, preencher com endereço completo - rua, número, bairro, cidade e CEP e telefone residenciais, no caso de

representante legal de pessoa juridica, informar o enderecoro: orgão representado)

a) Estar ciente de que os documentos originais relacionados são custodiados pela Biblioteca Nacional e que não será autorizada a fotografia ou filmagem de originais que possuam facsimiles, negativos ou diapositivos. Nesses casos serão usadas as cópias fac-similares, negativos ou diapositivos existentes - desde que apresentem a qualidade necessária para a reprodução;

b) Responsabilizar-me, no âmbito civil e penal, por quaisquer danos que possam ser causados aos documentos do acervo, instalações ou dependências da Fundação Biblioteca Nacional ou a terceiros, ressarcindo os prejuizos materiais que venham a ocorrer;

c) Estar ciente de que a Fundação Biblioteca Nacional não autoriza o uso da reprodução de obras protegidas pela Lei do Direito Autoral para nenhum outro fim que não o de pesquisa, cabendo ao usuário a obtenção da autorização para quaisquer fins comerciais;

d) Utilizar os documentos originais relacionados para uma única e exclusiva reprodução na obra

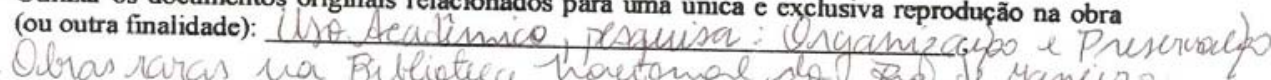

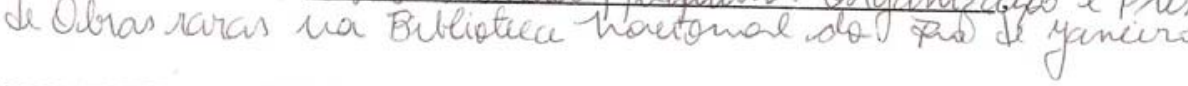

Conforme parecer do Escritório de Direitos Autorais da Fundação Biblioteca Nacional 
e) Estar de acordo em mencionar o crédito à Fundação Biblioteca Nacional por ocasião da sua utilizacão na forma: "Acervo da Fundação Biblioteca Nacional - Brasil"

f Assumir o compromisso de não utilizar as imagens em outros trabalhos, edições, tiragens c publicações que não os especificados na presente solicitação e não repassar a terceiros os documentos que me forem cedidos;

g) Remunerar a Fundação Biblioteca Nacional em retribuição pelo uso da imagem, quando for o caso, de acordo com os valores pré-determinados;

h) Fornecer à Fundação Biblioteca Nacional cópias do material reproduzido (cromos, negativos ou arquivos digitais).

Relação dos documentos a serem reproduzidos: CAMÓES, Luisde, 1524? - 1580. OA Lusiadass [C,002, 029 A ex. 1]

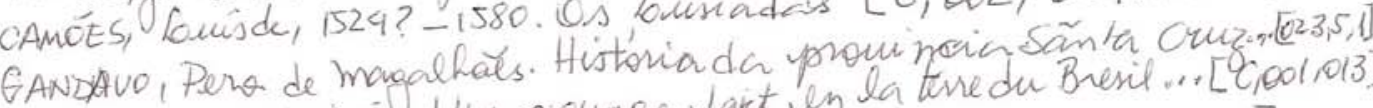
LERY, Yean de. Historie d'un vayage yauct en la terre du Bresil... [C,001,013]

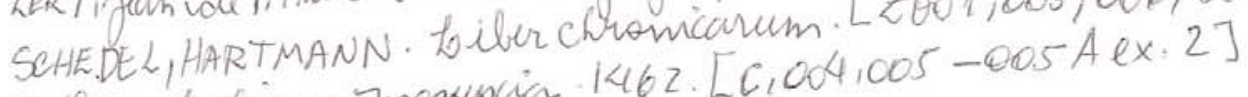
Bilia Loatima megancia 1462. L6,004,005 -

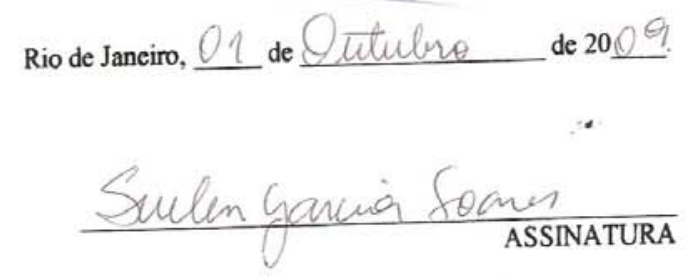

Autorizado em 01,1012009

I S n $n^{\circ} 29 F B N$ cobrança reprodução acervo 
Anexo C - Formulário de pedido

\begin{tabular}{|c|c|c|c|c|c|}
\hline \multicolumn{5}{|c|}{ 17. Mundação BIBLIOTECA NACIONAL } & $N^{0}$ da mesa / Table number \\
\hline Localizaçäo / Call number & \multicolumn{4}{|l|}{ Autor/Author } & Data / Date \\
\hline \multirow{2}{*}{$\begin{array}{l}\text { Rubrica do funcionário (salāo) } \\
\text { Employee initials (Room) }\end{array}$} & \multicolumn{4}{|l|}{ Titulo / Title } & $N^{0}$ do crachá / User card $n^{\circ}$ \\
\hline & \multicolumn{4}{|l|}{ Volume } & \multirow{6}{*}{$\begin{array}{l}\text { Escolaridade / Education } \\
\square 1^{\circ} \text { Grau / Elementary School } \\
\square 2^{\circ} \text { Grau / High School } \\
\square \text { Superior / University } \\
\square \text { Pós-Graduação / Post Graduate }\end{array}$} \\
\hline \multicolumn{5}{|l|}{ Nome / Name } & \\
\hline \multicolumn{5}{|l|}{ Endereço/Address } & \\
\hline \multicolumn{5}{|l|}{ Cidade / City } & \\
\hline \multicolumn{2}{|l|}{ Estado / State } & \multicolumn{3}{|l|}{ Pais / Country } & \\
\hline \multicolumn{2}{|l|}{ Tel. / Fax } & \multicolumn{3}{|l|}{ E-mail } & \\
\hline \multicolumn{5}{|c|}{ Observaçōes para uso da Instituição / Observations for internal use } & \multirow{3}{*}{$\begin{array}{l}\text { Rubrica do funcionário (Armazém) } \\
\text { Employee initials (Store Room) }\end{array}$} \\
\hline$\square$ Consulla $\square$ Microfilme & $\square$ Encadernação & D Diurno & Noturno & Sábado & \\
\hline \multicolumn{2}{|c|}{$\square$ Restauro $\square$ Fora de lugar $\square$ Ind. Errada } & $\square$ & $\square$ & $\square$ & \\
\hline
\end{tabular}

